Research report

\title{
A novel pleiotropic effect of aspirin: Beneficial regulation of pro- and anti- inflammatory mechanisms in microglial cells
} \author{
Karoly Gulya ${ }^{\mathrm{a}, *}$ \\ a Department of Cell Biology and Molecular Medicine, University of Szeged, Szeged, Hungary \\ b Department of Laboratory Medicine, University of Szeged, Szeged, Hungary \\ ${ }^{c}$ Avidin Ltd., Szeged, Hungary
}

Diana Kata ${ }^{\mathrm{a}}$, Imre Földesi ${ }^{\mathrm{b}}$, Liliana Z. Feher ${ }^{\mathrm{c}}$, Laszlo Hackler Jr. ${ }^{\mathrm{c}}$, Laszlo G. Puskas ${ }^{\mathrm{c}}$,

\section{A R T I C L E I N F O}

\section{Keywords:}

Aspirin

Anti-inflammation

Gene expression

Lipopolysaccharide

Phagocytosis

Pro-inflammation

\begin{abstract}
A B S T R A C T
Aspirin, one of the most widely used non-steroidal anti-inflammatory drugs, has extensively studied effects on the cardiovascular system. To reveal further pleiotropic, beneficial effects of aspirin on a number of pro- and anti-inflammatory microglial mechanisms, we performed morphometric and functional studies relating to phagocytosis, pro- and anti-inflammatory cytokine production (IL-1 $\beta$, tumor necrosis factor- $\alpha$ (TNF- $\alpha$ ) and IL10 , respectively) and analyzed the expression of a number of inflammation-related genes, including those related to the above functions, in pure microglial cells. We examined the effects of aspirin $(0.1 \mathrm{mM}$ and $1 \mathrm{mM})$ in unchallenged (control) and bacterial lipopolysaccharide (LPS)-challenged secondary microglial cultures. Aspirin affected microglial morphology and functions in a dose-dependent manner as it inhibited LPS-elicited microglial activation by promoting ramification and the inhibition of phagocytosis in both concentrations. Remarkably, aspirin strongly reduced the pro-inflammatory IL-1 $\beta$ and TNF- $\alpha$ production, while it increased the antiinflammatory IL-10 level in LPS-challenged cells. Moreover, aspirin differentially regulated the expression of a number of inflammation-related genes as it downregulated such pro-inflammatory genes as Nos2, Kng1, IL1ß, Ptgs2 or Ccr1, while it upregulated some anti-inflammatory genes such as IL10, Csf2, Cxcl1, Ccl5 or Tgfb1. Thus, the use of aspirin could be beneficial for the prophylaxis of certain neurodegenerative disorders as it effectively ameliorates inflammation in the brain.
\end{abstract}

\section{Introduction}

Microglia is the principal immune cell in the central nervous system (CNS). Under pathophysiological conditions such as injury, infection or neurodegeneration (Kettenmann et al., 2011; Kreutzberg, 1996) microglia become activated that proliferate, phagocytose and release pro- and anti-inflammatory cytokines, growth factors or reactive species (Gehrmann et al., 1995; Hanisch, 2002; Kreutzberg, 1996; Luo and Chen, 2012; Smith et al., 2012). Neuroinflammatory processes are strongly associated with the development of Alzheimer's disease (AD; Akiyama et al., 2000; McGeer and McGeer, 2004), Parkinson's disease
(PD; Phani et al., 2012; Shin et al., 2015) and multiple sclerosis (MS; Minagar et al., 2002; Muzio et al., 2007). In AD, for example, $\beta$-amyloid accumulation leads to the production of cytokines (IL-1 $\beta$, IL-6, TNF- $\alpha$ ) and the activation of nitric oxide synthase (Nos) gene through the nuclear transcription factor kappa B (NF-kB) signaling pathway (Medeiros et al., 2007). IL-1 $\beta$ in turn increases the expression of amyloid precursor protein (Ge and Lahiri, 2002), while increased expression of TNF- $\alpha$ is reported for both MS and PD (Minagar et al., 2002). Strong anti-inflammatory mechanisms can also lead to the development of neurodegenerative diseases (Gehrmann et al., 1995; Ghosh et al., 2013; Gonzalez-Scarano and Baltuch, 1999; Graeber,

\footnotetext{
Abbreviations: AD, Alzheimer's disease; Cd, cluster of differentiation; CNS, central nervous system; COX, cyclooxygenase (prostaglandin-endoperoxide synthase, EC 1.14.99.1); DIV,

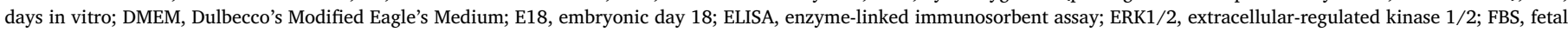

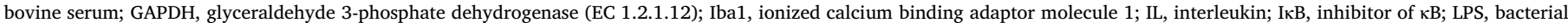

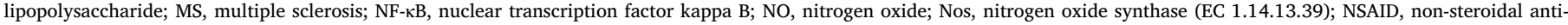

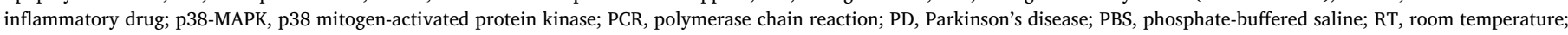

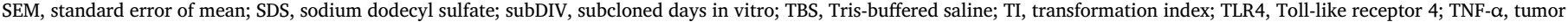
necrosis factor $\alpha$

* Corresponding author at: Department of Cell Biology and Molecular Medicine, University of Szeged, Somogyi u. 4, Szeged, H-6720, Hungary.

E-mail addresses: kata.diana@med.u-szeged.hu (D. Kata), foldesi.imre@med.u-szeged.hu (I. Földesi), 1.feher@avidinbiotech.com (L.Z. Feher), hackler@avidinbiotech.com (L. Hackler), laszlo@avidinbiotech.com (L.G. Puskas), gulyak@bio.u-szeged.hu (K. Gulya).
} 


\section{0; Streit, 2002).}

Aspirin (acetylsalicylic acid) is one of the most commonly used nonsteroidal anti-inflammatory drugs (NSAIDs). By inhibiting the enzyme cyclooxygenase (COX; prostaglandin-endoperoxide synthase, EC 1.14.99.1) it blocks the conversion of arachidonic acid to prostanoids (Vane and Botting, 2003). Apart from its well known beneficial antiinflammatory effects in the cardiovascular system (Amann and Peskar, 2002) and its role in anti-cancer therapy (Cuzick et al., 2014), it also has widespread effects on immune cell functions such as NO production, cytokine (e.g. IL-1 $\beta$, IL-6, IL-8, TNF- $\alpha$ ) and adhesion molecule expression (Hussain et al., 2012). Its anti-inflammatory function is based on the inhibition of the NF- $\mathrm{KB}$ signaling pathway (Amann and Peskar, 2002), while its neuroprotective effect in the injured brain is linked to COX-2 inhibition; overexpression of COX-2 is indicative of neuronal damage (Berk et al., 2013; Strauss, 2008). Although aspirin has not been extensively studied in microglia, its anti-inflammatory actions are recently reported (Medeiros et al., 2013; Wang et al., 2011; Yang et al., 2014).

In the present study we investigated the pleiotropic effects of aspirin on secondary, pure microglial cultures derived from mixed primary cultures of 18-day-old embryonic (E18) rat forebrains under control (unchallenged) and bacterial lipopolysaccharide (LPS)-challenged conditions (Gresa-Arribas et al., 2012; Kata et al., 2016; Lund et al., 2006). To reveal the effects of aspirin on pro- and anti-inflammatory mechanisms, we performed quantitative morphometric, functional and gene expression studies relating to phagocytic capability, pro- and antiinflammatory cytokine production (IL- $1 \beta$, TNF- $\alpha$, and IL-10, respectively) and the expression of various genes related to inflammation. A preliminary report on the effects of aspirin on pure microglial cultures was presented in poster form (Kata and Gulya, 2014).

\section{Material and methods}

\subsection{Animals}

All animal experiments were carried out in strict compliance with the European Council Directive (86/609/EEC) and EC regulations (O.J. of EC No. L 358/1, 18/12/1986) regarding the care and use of laboratory animals for experimental procedures, and followed the relevant Hungarian and local legislation requirements. The experimental protocols were approved by the Institutional Animal Welfare Committee of the University of Szeged (I-74-II/2009/MÁB). The pregnant Sprague-Dawley rats (170-190 g) were kept under standard housing conditions and fed ad libitum.

\subsection{Antibodies}

For a thorough characterization of different microglial phenotypes developed in vitro, an antibody against the ionized calcium binding adaptor molecule 1 (Iba1), an intracellular actin- and $\mathrm{Ca}^{2+}$-binding protein expressed in the CNS specifically in macrophages and microglia (Ahmed et al., 2007), was used in our immunocytochemical and Western blot analyses. The anti-glyceraldehyde 3-phosphate dehydrogenase (GAPDH) antibody was used as an internal control in Western blot experiments (Wu et al., 2012). Antibody dilutions, incubation times and blocking conditions were tested for both immunocytochemistry and Western blot analysis. To detect the specificities of the secondary antisera, staining without the primary antibody was performed. In such cases, no fluorescent or Western blot signals were detected.

\subsection{Cell cultures}

Pure microglial cells were isolated from mixed primary cortical cell cultures of rat embryos of either sex by the method we described earlier (Kata et al., 2016; Szabo and Gulya, 2013). Sibling embryos obtained from the same pregnancy were processed for culturing together; each pregnancy was considered as an independent experiment. Briefly, 10-12 fetal rats (E18) under anesthesia were decapitated and the frontal lobe of the cerebral cortex was removed, minced with scissors, incubated in $9 \mathrm{ml}$ Dulbecco's Modified Eagle's Medium (DMEM; Invitrogen, Carlsbad, USA) containing $1 \mathrm{~g} / \mathrm{l} \mathrm{D}$-glucose, $110 \mathrm{mg} / \mathrm{l} \mathrm{Na}$ pyruvate, $4 \mathrm{mM}$ L-glutamine, $3.7 \mathrm{~g} / 1 \mathrm{NaHCO}_{3}, 10,000 \mathrm{U} / \mathrm{ml}$ penicillin $\mathrm{G}, 10 \mathrm{mg} / \mathrm{ml}$ streptomycin sulfate, $25 \mu \mathrm{g} / \mathrm{ml}$ amphotericin B and $0.25 \%$ trypsin for $10 \mathrm{~min}$ at $37^{\circ} \mathrm{C}$, and then centrifuged at $1000 \mathrm{~g}$ for $10 \mathrm{~min}$ at room temperature (RT). The pellet was resuspended, washed twice in $5 \mathrm{ml}$ DMEM containing 10\% heat-inactivated fetal bovine serum (FBS; Invitrogen) and centrifuged for $10 \mathrm{~min}$ at $1000 \mathrm{~g}$ at RT. The final pellet was resuspended in $2 \mathrm{ml}$ DMEM/10\% FBS, after which the cells were plated in the same medium on a poly-L-lysine-coated culture flask $\left(75 \mathrm{~cm}^{2}, 12 \times 10^{6}\right.$ cell/flask) and cultured for a number of days in vitro (DIV) at $37{ }^{\circ} \mathrm{C}$ in a humidified air atmosphere supplemented with $5 \%$ $\mathrm{CO}_{2}$, in one or other of the following ways: 1 ) in poly-L-lysine-coated coverslips $\left(15 \times 15 \mathrm{~mm} ; 2 \times 10^{5}\right.$ cells/coverslip) for immunocytochemistry; 2) in poly-L-lysine-coated Petri dishes $(60 \mathrm{~mm} \times 15 \mathrm{~mm}$; $4 \times 10^{5}$ cells/dish) for Western blot and enzyme-linked immunosorbent assays (ELISA); or 3) in a poly-L-lysine-coated culture flask $\left(75 \mathrm{~cm}^{2}, 12 \times 10^{6}\right.$ cells/flask) for the subsequent generation of pure microglial cell cultures.

Secondary microglial cells were subcloned from mixed primary cultures (DIV7) maintained in a poly-L-lysine-coated culture flask $\left(75 \mathrm{~cm}^{2}, 12 \times 10^{6}\right.$ cells/flask) by shaking the cultures at $100 \mathrm{rpm}$ in a platform shaker for $30 \mathrm{~min}$ at $37^{\circ} \mathrm{C}$. Microglia from the supernatant were collected by centrifugation at $3000 \mathrm{~g}$ for $8 \mathrm{~min}$ at RT and resuspended in $2 \mathrm{ml}$ DMEM/10\% FBS. The cells were seeded at a density of $4 \times 10^{5}$ cells/Petri dish for Western blots or $2 \times 10^{5}$ cells/ coverslip/Petri dish for immunocytochemistry or phagocytosis assays, and cultured in DMEM in a humidified atmosphere supplemented with $5 \% \mathrm{CO}_{2}$ at $37^{\circ} \mathrm{C}$. The medium was changed on the first day after seeding (subDIV1).

\subsection{Cell culture treatments}

The aspirin concentrations used in our study are comparable to the therapeutic plasma salicylate levels for pain relief, inhibition of platelet aggregation or anti-inflammation (Higgs et al., 1987). On the fourth day of subcloning (subDIV4), DMEM was replaced and the expanded pure microglial cells were treated with either bacterial lipopolysaccharide (LPS; $20 \mathrm{ng} / \mathrm{ml}$ final conc., dissolved in DMEM; Sigma, St. Louis, MO, USA) or aspirin ( $0.1 \mathrm{mM}$ (low) and $1 \mathrm{mM}$ (high) final conc., from $\geq 99 \%$ acetylsalicylic acid dissolved in sterile, distilled water; Sigma) alone, or with a combination of LPS + aspirin, and the effects were compared in a variety of morphological and functional tests. LPS treatment served as an immunochallenge. Six types of treatment regimens were used: 1 ) control (unchallenged and untreated) cultures; 2) LPS-challenged cultures received $20 \mathrm{ng} / \mathrm{ml} \mathrm{LPS}$; 3) aspirin-treated cultures received $0.1 \mathrm{mM}$ aspirin; 4) aspirin-treated cultures received $1 \mathrm{mM}$ aspirin; 5) LPS-challenged + aspirin-treated cultures were challenged with $20 \mathrm{ng} / \mathrm{ml}$ LPS and treated with $0.1 \mathrm{mM}$ aspirin; 6) LPSchallenged + aspirin-treated cultures were challenged with $20 \mathrm{ng} / \mathrm{ml}$ LPS and received $1 \mathrm{mM}$ aspirin. Depending on the experiments, the treatments lasted for 6 or $24 \mathrm{~h}$ at $37^{\circ} \mathrm{C}$.

\subsection{Immunocytochemistry}

Pure secondary microglial cultures treated with different treatment regimens were fixed on coverslips with $4 \%$ formaldehyde for $5 \mathrm{~min}$ and rinsed with $0.05 \mathrm{M}$ phosphate-buffered saline (PBS) for $2 \times 5 \mathrm{~min}$. After permeabilization and blocking of the nonspecific sites in $0.05 \mathrm{M}$ PBS solution containing 5\% normal goat serum (Sigma), 1\% heatinactivated bovine serum albumin (Sigma) and $0.05 \%$ Triton X-100 for $30 \mathrm{~min}$ at $37^{\circ} \mathrm{C}$, the cells on the coverslips were incubated overnight in 
a humidified chamber at $4{ }^{\circ} \mathrm{C}$ with rabbit anti-Iba1 polyclonal antibody (1:500 final dilution; Wako, Japan) in the above solution (Kata et al., 2016). The cultured cells were washed for $4 \times 10 \mathrm{~min}$ at RT in $0.05 \mathrm{M}$ PBS, and then incubated with the Alexa Fluor 568 fluorochromeconjugated goat anti-rabbit antibody (1:1000 final dilution; Invitrogen) in the dark for $3 \mathrm{~h}$ at RT. The cells on the coverslip were washed for $4 \times 10 \mathrm{~min}$ in $0.05 \mathrm{M}$ PBS at RT, and the nuclei were stained in $0.05 \mathrm{M}$ PBS solution containing $1 \mathrm{mg} / \mathrm{ml}$ polyvinylpyrrolidone and $0.5 \mu \mathrm{l} / \mathrm{ml}$ Hoechst 33258 dye (Sigma). The coverslips were rinsed in distilled water for $5 \mathrm{~min}$, air-dried and mounted on microscope slides in Vectashield mounting medium (Vector Laboratories, Burlingame, CA, USA).

\subsection{Western blot analysis}

Cultured microglial cells (subDIV4) were collected through use of a rubber policeman, homogenized in $50 \mathrm{mM}$ Tris- $\mathrm{HCl}(\mathrm{pH} 7.5)$ containing $150 \mathrm{mM} \mathrm{NaCl}, 0.1 \%$ Nonidet P40, $0.1 \%$ cholic acid, $2 \mu \mathrm{g} / \mathrm{ml}$ leupeptin, $1 \mu \mathrm{g} / \mathrm{ml}$ pepstatin, $2 \mathrm{mM}$ phenylmethylsulfonyl fluoride and $2 \mathrm{mM}$ EDTA, and centrifuged at $10,000 \mathrm{~g}$ for $10 \mathrm{~min}$ (Kata et al., 2016; Szabo and Gulya, 2013). The pellet was discarded and the protein concentration of the supernatant was determined (Lowry et al., 1951). For the Western blot analyses, 5-10 $\mu \mathrm{g}$ of protein was separated on a sodium dodecyl sulfate/polyacrylamide gel (4\%/10\% stacking gel/ resolving gel), transferred onto Hybond-ECL nitrocellulose membrane (Amersham Biosciences, Little Chalfont, Buckinghamshire, England), blocked for $1 \mathrm{~h}$ in $5 \%$ nonfat dry milk in Tris-buffered saline (TBS) containing $0.1 \%$ Tween 20 , and incubated overnight with either a rabbit anti-Iba1 polyclonal antibody (1:1000 final dilution; Wako) or a mouse anti-GAPDH monoclonal antibody (clone GAPDH-71.1; 1:20,000 final dilution; Sigma). The membranes were rinsed 5 times in $0.1 \%$ TBSTween 20 and incubated for $1 \mathrm{~h}$ with the peroxidase-conjugated goat anti-rabbit secondary antibody (1:2000 final dilution; Invitrogen) for Iba1 or with the peroxidase-conjugated rabbit anti-mouse secondary antibody (1:2000 final dilution; Sigma) for GAPDH Western blots, then washed 5 times as before. The enhanced chemiluminescence method (ECL Plus Western blotting detection reagents; Amersham Biosciences) was used to reveal immunoreactive bands according to the manufacturer's protocol.

\subsection{In vitro phagocytosis}

The fluid-phase phagocytic capabilities of the control and variously treated pure microglial cell cultures were determined via the uptake of fluorescent microspheres (carboxylate-modified polystyrene beads, fluorescent yellow-green ( $\lambda \mathrm{ex} \sim 470 \mathrm{~nm}$; $\lambda \mathrm{em} \sim 505 \mathrm{~nm}$ ), aqueous suspension, $2.0 \mu \mathrm{m}$ mean particle size; L4530, Sigma) as we described previously (Szabo and Gulya, 2013; Szabo et al., 2016). Unchallenged (control) and LPS-challenged pure microglial cell cultures (subDIV4) with or without aspirin treatments were tested for $24 \mathrm{~h}$. At the end of the treatment period, $1 \mu \mathrm{l}$ of a $2.5 \%$ aqueous suspension of fluorescent microspheres per $\mathrm{ml}$ was added to the culture, which was then incubated for $60 \mathrm{~min}$ at $37^{\circ} \mathrm{C}$. The cells were next washed 5 times with $2 \mathrm{ml}$ of $\mathrm{PBS}$ to remove dish- or cell surface-bound residual fluorescent microspheres, and fixed with $4 \%$ formaldehyde in PBS. In another setup, we also determined the number of cell membraneassociated but not phagocytosed beads. Such negative controls were treated as above with the exception that microglial cultures with beads were incubated for $60 \mathrm{~min}$ at $4{ }^{\circ} \mathrm{C}$. At this temperature, the number of beads associated with cell surface averaged less than 1 bead/100 Iba1labeled cells, thus the phagocytosis was not considered significant. For measurement of the phagocytotic activity, cells labelled with phagocytosed microbeads and processed for Iba1 immunocytochemistry were counted in 20 random fields in each treatment group (mean \pm SEM) under a $20 \times$ or $40 \times$ objective. Statistically significant differences were determined by two-way ANOVA.

\subsection{Determination of $I L-1 \beta, I L-10$ and TNF- $\alpha$}

Our protocols for ELISA assays were described previously (Kata et al., 2016). Briefly, the supernatants were collected from each treatment and stored at $-20^{\circ} \mathrm{C}$. Concentrations of IL-1 $\beta$, IL-10 and TNF- $\alpha$ were measured with rat-specific ELISA kits (eBioscience, Vienna, Austria). The sensitivity of IL-1 $\beta$ (Cat\# BMS630), IL-10 (Cat\# BMS629) and TNF- $\alpha$ (Cat\#BMS622) assays was $4 \mathrm{pg} / \mathrm{ml}, 1.5 \mathrm{pg} / \mathrm{ml}$ and $11 \mathrm{pg} /$ $\mathrm{ml}$, respectively. As stated by the manufacturer, the overall intra- and interassay coefficients of variation were $<10 \%$ in both cases for IL-1 $\beta$ and TNF- $\alpha$, and $<5 \%$ in both cases for IL- 10 .

\subsection{RNA isolation}

Total RNA from control and treated pure microglial cells was purified as described previously (Fabian et al., 2011); columns and wash buffer were from Bioneer (Viral RNA extraction kit; Daejon, South Korea). Briefly, cells were washed with PBS, incubated in lysis buffer (RA1; Macherey-Nagel, Düren, Germany), then collected and mixed with $70 \%$ ethanol in RNase-free water (Bioneer). The mixture was transferred through columns (Bioneer) and washed with $350 \mu \mathrm{l} 80 \%$ ethanol in diethylpyrocarbonate-treated water, and then with $600 \mu \mathrm{l}$ and $300 \mu \mathrm{l}$ W2 wash buffer (Bioneer). Total RNA was eluted in $50 \mu \mathrm{l}$ RNase free-water. One $\mu$ l RNase inhibitor (Applied Biosystems, Foster City, CA, USA) was added to the samples. The quality and quantity of the isolated RNA was measured with NanoDrop1000 Version 3.8.1. (Thermo Scientific, Budapest, Hungary).

\subsection{RNA expression}

Reverse transcription from $3 \mu \mathrm{g}$ total RNA in $30 \mu \mathrm{l}$ was performed with the High Capacity cDNA Archive Kit (Applied Biosystems) according to the manufacturer's protocol as described previously (Kata et al., 2016). cDNA was diluted to $80 \mu \mathrm{l}$ with nuclease-free water. The instrumentation included the Bravo automatic liquid handling system (Agilent Technologies, Inc., Santa Clara, CA, USA) for polymerase chain reaction (PCR) assay preparation and a LightCycler 1536 System (Roche Diagnostics Corp., Indianapolis, IN, USA) or a Light Cycler Nano Instrument (Roche) for cycling (Woudstra et al., 2013). The expression of 116 inflammationrelated genes, together with that of 6 control genes (see below), was measured with Universal Probe Library assays using intron-spanning genespecific primers (Rat Immune Panel; Avidin Ltd., Szeged, Hungary, www. avidinbiotech.com/custom-pathways/) and the LightCycler 1536 DNA Probe Master kit (Roche). Moreover, the expression of certain phagocytosis-related genes such as the integrin associated protein or cluster of differentiation 47 (Cd47, NM_019195_2), the engulfment or cell motility protein (Elmo1, NM_001108415.1), the scavenger receptor class B member 1 (Scarb1, NM_031541_1), the plasminogen activator inhibitor-1 (Serpine1, NM_012620_1), the signal-regulatory protein $\alpha$ (Sirpa, NM_013016_2) and the vesicle-associated membrane protein 7 (Vamp7, NM_053531_1) were also analyzed by the Light Cycler Nano Instrument. For the 1536 System, each $2 \mu \mathrm{l} \mathrm{PCR}$ reaction contained $8 \mathrm{ng}$ cDNA, $0.4 \mu \mathrm{l}$ LightCycler DNA Probes Master $(5 \mathrm{x})$, the corresponding primer set and UPL probe and the Setup Control (Kata et al., 2016). The PCR cycling protocol was as follows: enzyme activation at $95^{\circ} \mathrm{C}$ for $60 \mathrm{~s}, 50$ cycles of denaturation at $95^{\circ} \mathrm{C}$ for $0 \mathrm{~s}$, and annealing and extension at $60^{\circ} \mathrm{C}$ for $30 \mathrm{~s}$. For the Nano Instrument, each $20 \mu \mathrm{l}$ PCR reaction contained $20 \mathrm{ng}$ cDNA, $10 \mu \mathrm{l}$ Lightcycler DNA Probes Master (5x), the corresponding primer set and UPL probe and the Setup Control. The PCR protocol was as follows: enzyme activation at $95^{\circ} \mathrm{C}$ for $10 \mathrm{~min}, 50$ cycles of denaturation at $95^{\circ} \mathrm{C}$ for $15 \mathrm{~s}$, and annealing and extension at $60{ }^{\circ} \mathrm{C}$ for $30 \mathrm{~s}$. Gene expression was normalized to the average values of clathrin, heavy chain (Cltc, NM_019299.1), Gapdh (M17701.1), glucuronidase, beta (Gusb, NM_017015.2), hypoxanthine phosphoribosyltransferase 1 (Hprt1, NM_012583.2), phosphoglycerate kinase 1(Pgk1, NM_053291.3), and tubulin, beta 5 class I (Tubb5, NM_173102.2) expression as endogenous 
controls and expressed relative to the unchallenged controls by using the $2^{-\Delta \Delta \mathrm{Ct}}$ method.

A total of 122 gene-specific assays were run on 3 independent samples from each condition. Student's $t$-test and two-way ANOVA were applied for the analysis of significance where $p<0.05$ was considered significant. Gene expression was analyzed by GraphPad Prism 6 (GraphPad Software, Inc., La Jolla, CA, USA). For hierarchical cluster analysis and visualization, the Hierarchical Clustering Explorer (v3.0) software was used (Human-Computer Interaction Lab., University of Maryland, MD, USA; publicly available at http://www. cs.umd.edu/hcil/multi-cluster/hce3.html). The complete linkage clustering method was applied with Euclidean distance metric.

\subsection{Image analysis and statistics}

Digital images were captured by a Nikon Microphot-FXA epifluorescent microscope (Nikon Corp., Tokyo, Japan), using a Spot RT Color CCD camera and the Spot RT software (Spot RT/ke Diagnostic Instruments, Sterling Heights, MI, USA). For the determination of microglial cell purity, Hoechst 33258-labelled cell nuclei that belonged to Iba1-immunopositive cells were counted on coverslip-cultured samples. For each culture, 50-100 randomly selected microscope fields were analyzed. In every case, the cultures had, on average, at least 99 Iba1-positive somata for 100 Hoechst 33258-labelled cell nuclei ( $>99 \%$ purity for microglial cells). Phagocytosed microspheres on 20 randomly sampled microscope fields from 3 coverslips for each treatment regimen were counted with the use of the computer program ImageJ (version 1.47; http://rsb.info.nih.gov/ij). For the measurement of area $\left(\mu \mathrm{m}^{2}\right)$, perimeter $(\mu \mathrm{m})$ and transformation index (TI), Iba1immunoreactive microglial cell images were converted into binary replicas by using thresholding procedures implemented by ImageJ and Adobe Photoshop CS5.1 software (Adobe Systems, Inc., San Jose, CA, USA) as we published earlier (Kata et al., 2016; Szabo and Gulya, 2013; Szabó et al., 2016). TI was determined (Fujita et al., 1996) according to the following formula: [perimeter of cell $(\mu \mathrm{m})]^{2} / 4 \pi$ [cell area $\left(\mu \mathrm{m}^{2}\right)$ ]. Color correction and cropping of the light microscopic images were performed when photomicrographs were made for publication and assembled for a panel. Gray-scale digital images of the immunoblots were acquired by scanning the autoradiographic films with a desktop scanner and processed at identical settings to allow comparisons of the Western blots from different samples. The bands were analyzed through the use of ImageJ. The immunoreactive densities of equally loaded lanes were quantified, and all samples were normalized to the internal GAPDH load controls.

All statistical comparisons were made by using R 3.1.0 for Windows (The R Foundation for Statistical Computing; Vienna University of Economics and Business, Vienna, Austria). Results were analyzed with two-way ANOVA, and the Bonferroni correction was used to establish significance between groups. Values were presented as means \pm SEM; $\mathrm{p}<0.05$ was considered significant; *,** and $* * *$ denote $\mathrm{p}<0.05$, $\mathrm{p}<0.01$ and $\mathrm{p}<0.001$, respectively.

\section{Results}

\subsection{Aspirin regulates microglial morphology in vitro}

Microglial morphology was analyzed on pure microglial cultures 4 days after seeding (subDIV4). Immunocytochemistry routinely performed on these secondary cultures consistently detected a $>99 \%$ incidence of the Iba1 immunopositive microglial cells for the Hoechst 33258 dye-labeled cell nuclei (Fig. 1). The morphological changes elicited by aspirin treatments in unchallenged and LPS-challenged pure microglia cultures (Fig. 2A-F) were quantitatively analyzed on binary silhouettes of individual microglial cells (Fig. $3 A-I$ ). Iba1 protein expression was also monitored during treatments (Fig. 2G). The amount of Iba1 immunoreactivity was significantly increased in the aspirin-treated (low:

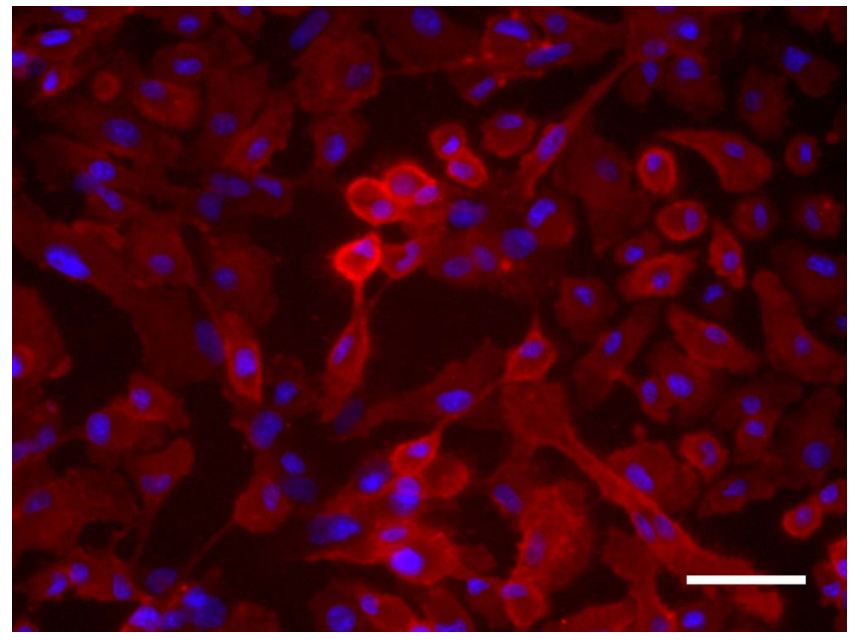

Fig. 1. Localization of Iba1 immunoreactive microglial cells in a pure secondary microglial culture (subDIV4).

The typical purity of the culture is $>99 \%$; in this representative photomicrograph of a field of view the purity is $100 \%$ since every Hoechst 33258 -labeled cell nuclei (blue) is surrounded by Iba1 immunopositive cytoplasm (red). Scale bar: $50 \mu \mathrm{m}$.

$2.09 \pm 0.17$; high: $2.22 \pm 0.26$ ) and the LPS-challenged + aspirintreated groups (low: $2.30 \pm 0.29$; high: $2.49 \pm 0.32$ ) as compared to LPS-challenged values (1.35 \pm 0.14 ; Fig. $2 G$ ). Most of the unchallenged and untreated (control) microglia displayed slightly amoeboid/ramified morphology with $\mathrm{TI}=6.44 \pm 1.33$; they typically had only a few short processes (Figs. $2 A, 3 A$ ). LPS challenge resulted in a significant change in morphology (Figs. $2 B, 3 B, G-I$ ) as amoeboid morphologies with low TI values $(1.37 \pm 0.03)$ were more typical; LPS challenge decreased area, perimeter and TI values (by $48 \%, 65 \%$ and $78 \%$, respectively) as compared to the controls. When LPS-challenged cells were treated with aspirin, significantly enlarged and more ramified cells were seen as compared to the values of the LPS-challenged cells (Figs. $2 B, E, F, 3 B$, $E-I$ ) indicating that aspirin was able to reverse the morphological changes induced by LPS-challenge. Both aspirin doses increased the TI values to the control level (low: $5.73 \pm 0.56$; high: $7.36 \pm 0.61$ ) and induced ramified morphology with thick processes and microspikes (Figs. $2 E, F$; $3 E, F)$.

\subsection{Aspirin inhibits increases in LPS-induced phagocytosis by microglia}

Unchallenged and untreated microglia exhibited a low level of fluidphase phagocytosis engulfing only $3.63 \pm 0.21$ beads per cell $(n=60$; Fig. $4 A, G$ ). As expected, microglial activation was associated with robust phagocytic activity as LPS challenge increased phagocytosis significantly to about $350 \%$ of the control level (12.87 $\pm 0.65 ; \mathrm{n}=58$; Fig. $4 A, B, G)$. Aspirin alone did not affect the phagocytosis appreciably (Fig. $4 C, D, G$ ), as the number of phagocytosed microbeads remained low in both cases (low: $2.72 \pm 1.19$, high: $3.30 \pm 0.22 ; \mathrm{n}=60$ ). However, aspirin inhibited phagocytosis significantly in LPS-challenged microglia (Fig. 4E, $F, G$ ). Aspirin $(0.1 \mathrm{mM}$ or $1 \mathrm{mM})$ decreased phagocytosis dose-dependently by about $30 \%(9.20 \pm 0.59 ; \mathrm{n}=55$; Fig. $4 E, G)$ and $70 \%(3.86 \pm 0.23$ microbeads per cell; $\mathrm{n}=67$; Fig. $4 F, G$ ), respectively, as compared to LPS treatment.

\subsection{Aspirin strongly influences both pro- and anti-inflammatory cytokine} levels

Activated microglia express several inflammatory cytokines. When the basal levels of the pro-inflammatory cytokines IL-1 $\beta$ and TNF- $\alpha$ and the anti-inflammatory cytokine IL-10 in unchallenged microglia were compared with the levels from aspirin-treated LPS-challenged cells, a unique regulatory pattern emerged (Fig. 5). In the case of IL-1 $\beta$ the basal level in 

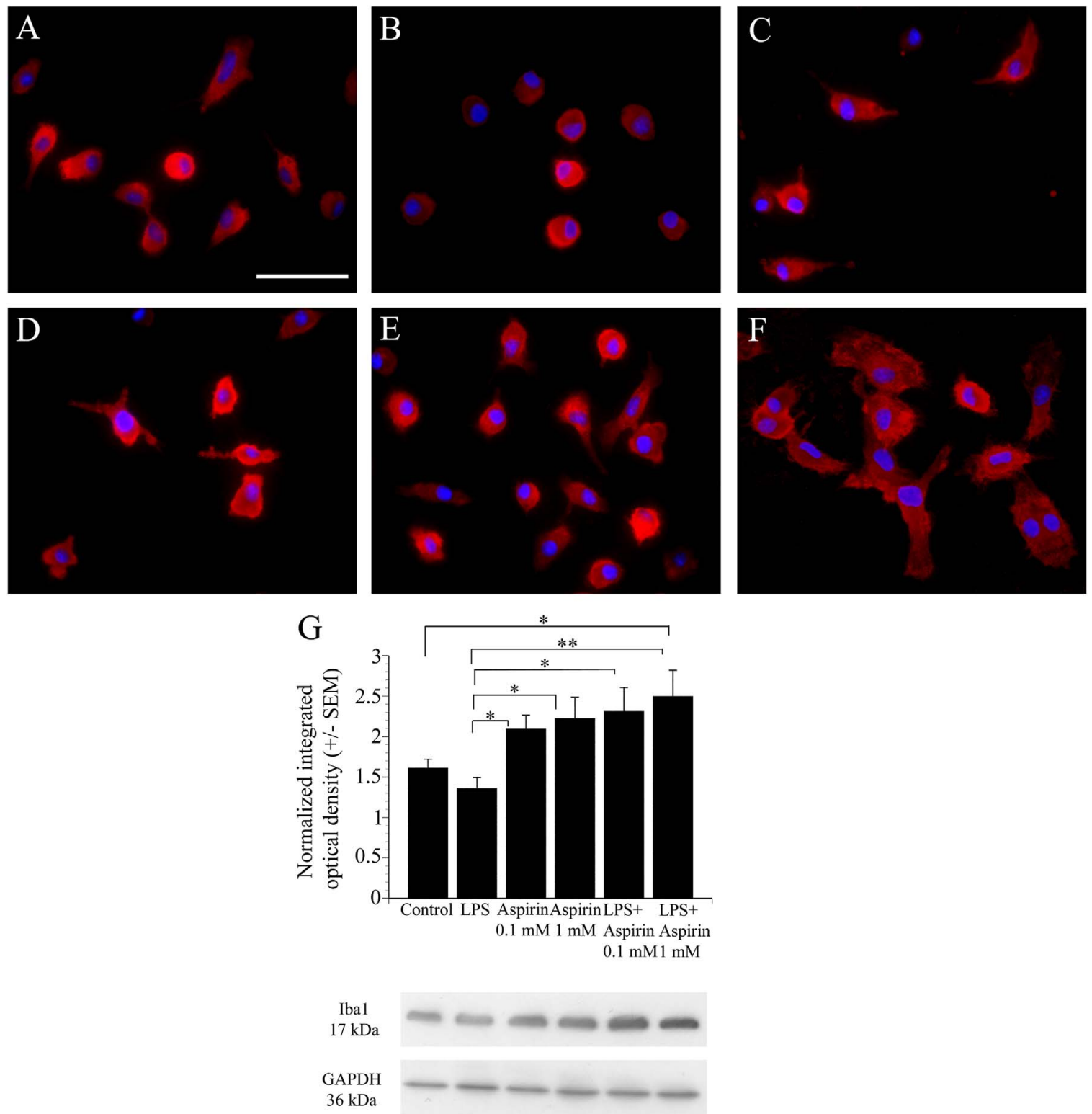

Fig. 2. Aspirin affects microglial morphology and Iba1 immunoreactivity in pure microglial cells.

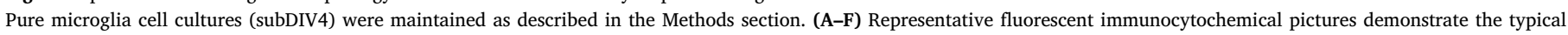

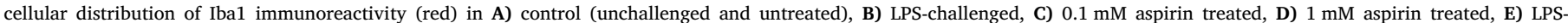

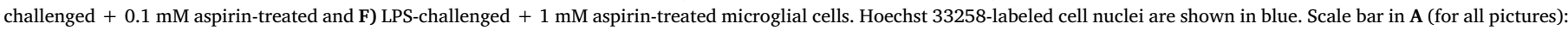

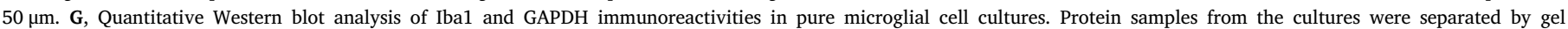

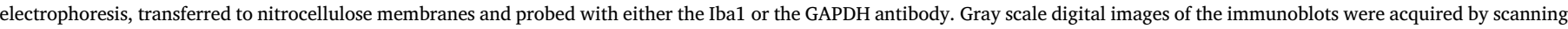

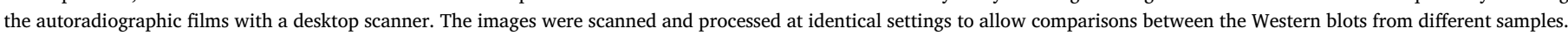

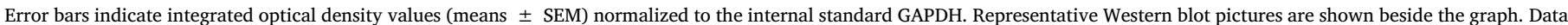
were analyzed with two-way analysis of variance (ANOVA). *p $<0.05$, **p $<0.01$.

unchallenged (control) microglia was $22.45 \pm 2.87 \mathrm{pg} / \mathrm{ml}$ (Fig. $5 A$ ). Both aspirin treatments were able to change this level (low: $10.26 \pm 2.62 \mathrm{pg}$ / $\mathrm{ml}$; high: $10.19 \pm 2.23 \mathrm{pg} / \mathrm{ml}$ ). As expected, LPS challenge significantly elevated the IL-1 $\beta$ level to $336.15 \pm 51.72 \mathrm{pg} / \mathrm{ml}$. However, co-incubation of LPS and $1 \mathrm{mM}$ aspirin significantly inhibited IL-1 $\beta$ level by about $50 \%$, to $169.6 \pm 19.42 \mathrm{pg} / \mathrm{ml}$, while $0.1 \mathrm{mM}$ aspirin decreased it by about $16.5 \%$, to $280.05 \pm 25.0 \mathrm{pg} / \mathrm{ml}$ (Fig. $5 A$ ).

A similarly strong effect of aspirin was demonstrated on the level of TNF- $\alpha$, another pro-inflammatory cytokine, in LPS-challenged microglial cells (Fig. $5 C, D$ ). Two different treatment periods ( $6 \mathrm{~h}$ and $24 \mathrm{~h}$ ) were used as the TNF- $\alpha$ production responded quickly to the LPS challenge. The level of TNF- $\alpha$ in the control group could not be detected, but its level quickly rose, to $1187 \pm 94.12 \mathrm{pg} / \mathrm{ml}$ in the LPS-challenged cells after $6 \mathrm{~h}$, and the level was still elevated after $24 \mathrm{~h}(189.92 \pm 27.4 \mathrm{pg} / \mathrm{ml})$. Aspirin treatments $(0.1 \mathrm{mM}$ and $1 \mathrm{mM})$ resulted in small, detectable TNF- $\alpha$ levels for both doses $(27.69 \pm 2.89 \mathrm{pg} / \mathrm{ml}$ and $29.23 \pm 1.73 \mathrm{pg} / \mathrm{ml}$ after $6 \mathrm{~h}$, while $8.24 \pm 1.81 \mathrm{pg} / \mathrm{ml}$ and $9.09 \pm 0.6 \mathrm{pg} / \mathrm{ml}$ after $24 \mathrm{~h}$ ). When aspirin was co-administered to LPS-challenged cells for either $6 \mathrm{~h}$ or $24 \mathrm{~h}$, it inhibited the production of TNF- $\alpha$ in both doses: $1 \mathrm{mM}$ aspirin decreased the TNF- $\alpha$ level significantly by about $25 \%$ (to $844.76 \pm 67.11 \mathrm{pg} / \mathrm{ml}$ after $6 \mathrm{~h})$ and $50 \%(96.79 \pm 6.02 \mathrm{pg} / \mathrm{ml}$ after $24 \mathrm{~h}$ ), and $0.1 \mathrm{mM}$ aspirin inhibited its level after $6 \mathrm{~h}$ by about $16 \%$ (to $946.95 \pm 84.74 \mathrm{pg} / \mathrm{ml}$ ) (Fig. 5C, D).

Aspirin also affected the production of IL-10 (Fig. 5B). LPS challenge 
increased the basal IL-10 level $(24.98 \pm 3.47 \mathrm{pg} / \mathrm{ml})$ significantly $(134.0 \pm 9.9 \mathrm{pg} / \mathrm{ml})$. When aspirin was co-administered with LPS, the IL-10 protein expression was further increased as compared to the LPS challenged value (low: $309.47 \pm 12.29 \mathrm{pg} / \mathrm{ml}$, high: $280.95 \pm 30.3 \mathrm{pg}$ / $\mathrm{ml}$ ). Aspirin administered alone to unchallenged cells had no significant effects on the microglial IL-10 levels.
A

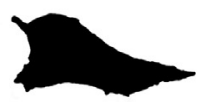

A: 546.26

P: 221.57

B

LPS

$\mathrm{C}$

Aspirin

$0.1 \mathrm{mM}$

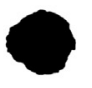

A: 244.17

P: 67.27

TI: 1.47

D

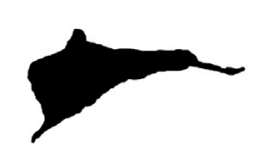

A: 580.16

P: 173.08

TI: 4.11

Aspirin

$1 \mathrm{mM}$

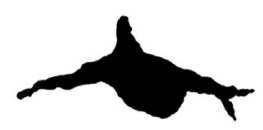

A: 536.95

P: 200.61

E

TI: 5.96

LPS+

Aspirin

$0.1 \mathrm{mM}$

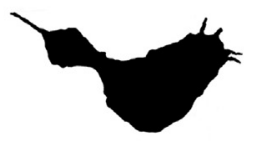

A: 771.82

P: 233.75

F

LPS+

Aspirin

$1 \mathrm{mM}$

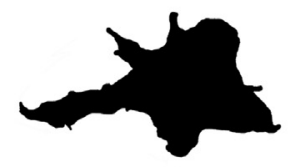

A: 1188.18

P: 354.65

TI: 8.42

G

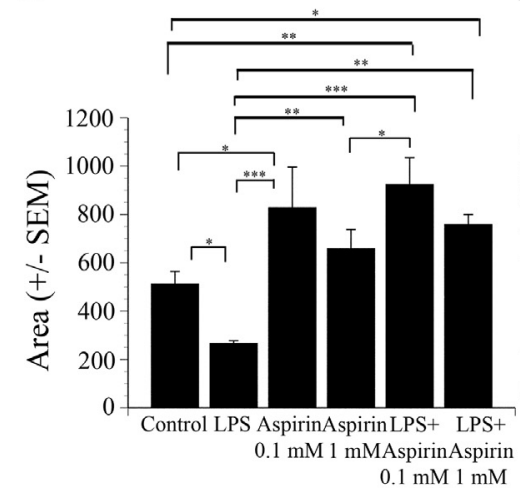

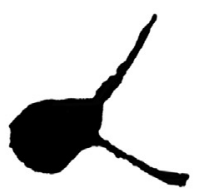

A: 796.12

P: 280.22

TI: 7.85

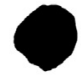

A: 228.37

P: 62.08

TI: 1.34

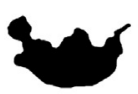

A: 352.52

P: 120.96

TI: 3.30

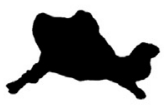

A: 482.57

P: 147.30

TI: 3.58

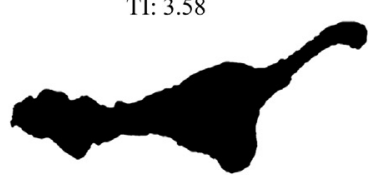

A: 1305.92

P: 273.17

TI: 4.55

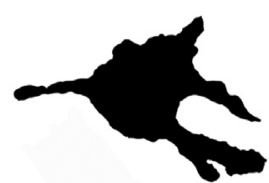

A: 1022.96

P: 292.92

TI: 6.67

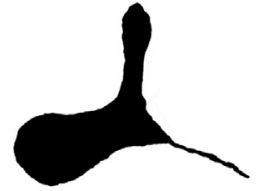

A: 381.97

P: 183.81

TI: 7.04

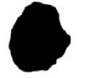

A: 234.69

P: 60.98

TI: 1.26

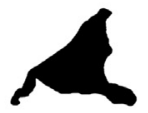

A: 352.21

P: 124.95

TI: 3.52

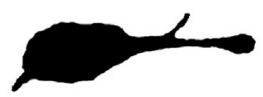

A: 531.26

P: 185.25

TI: 5.14

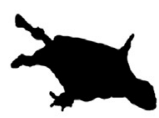

A: 466.76

P: 171.57

TI: 5.02

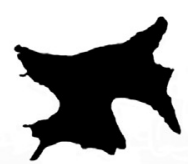

A: 884.66

P: 270.35

TI: 6.57

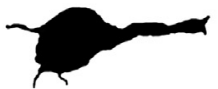

A: 585.08

P: 179.55

TI: 4.39

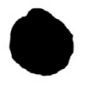

A: 241.23

P: 62.24

TI: 1.28

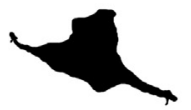

A: 377.66

P: 150.72

TI: 4.79

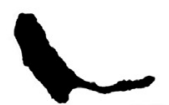

A: 265.40

P: 118.59

TI: 4.22

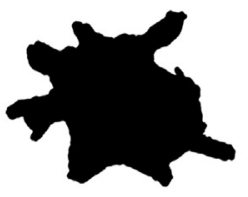

A: 1596.80

P: 285.93

TI: 4.07

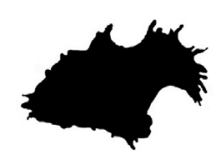

A:948.96

P: 283.64

TI: 6.74
$\mathrm{H}$

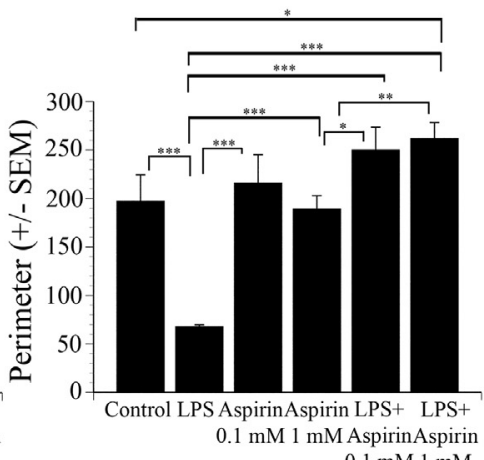

I

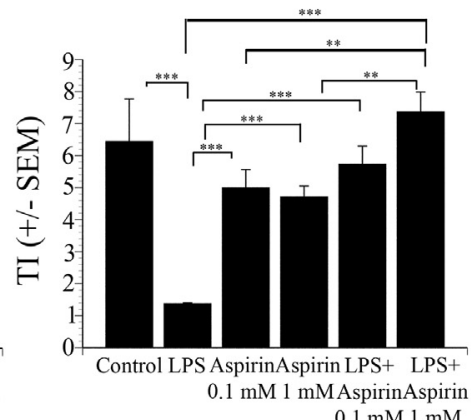

(caption on next page) 
Fig. 3. Quantitative analysis of microglial morphology in pure microglial cell cultures after different treatments.

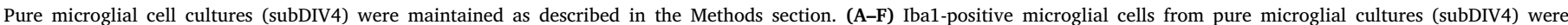

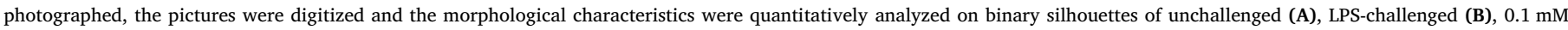

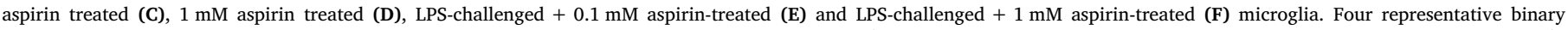

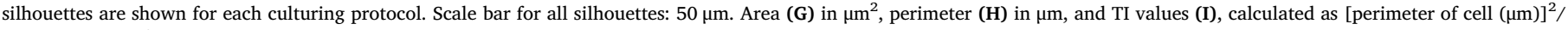

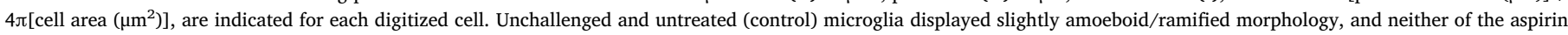

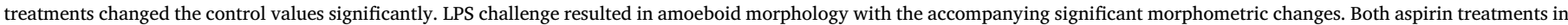

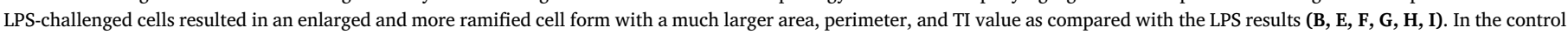

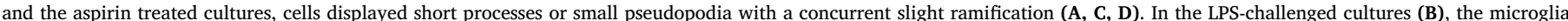

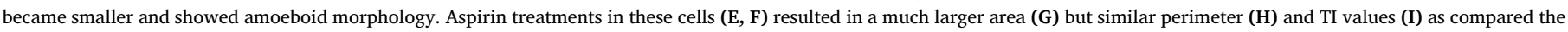

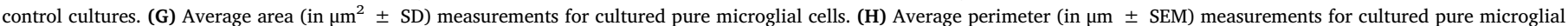

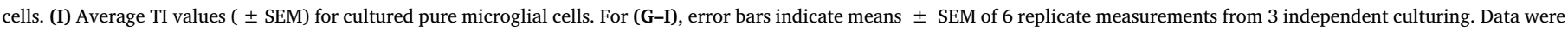
analyzed with two-way analysis of variance (ANOVA). ${ }^{*} \mathrm{p}<0.05,{ }^{* *} \mathrm{p}<0.01$, ${ }^{* * *} \mathrm{p}<0.001$

\subsection{Aspirin affects the expression of inflammation-related genes}

We analyzed the effects of aspirin on the expression of 116 inflammation-related genes in unchallenged and LPS-challenged pure microglial cells with or without aspirin treatment. The hierarchical cluster analysis of 46 such genes is summarized in Fig. 6, and those with the most noteworthy and significant expression changes in response to the treatments are listed in Table 1 . The genes upregulated by the LPS challenge included those coding for chemokine ligands 1, 2, 4, 5, 7, 9
$($ Cxcl1 $=84.30$-fold, $C c l 2=16.95$-fold, $C c l 4=9.80$-fold, $C c l 5=38.26$ fold, Cxcl5 = 33.19, Cxcl9 = 73.44-fold,) IL-1ß (Il1 $\beta=24.70$-fold), IL-6 receptor (Il6 $=7.57$-fold) and nitric oxide synthase (Nos2 $=369.22$-fold). Only a few genes were downregulated by the LPS challenge, including Tgfb2 (-1.73-fold), Sirpa (-2.42-fold), Tlr5 (-3.42-fold) and Myl2 (-4.46-fold).

The levels of expression of some inflammation-related genes strongly downregulated by aspirin are highlighted in Fig. 7. Aspirin treatment in unchallenged cells affected fewer, but similarly important
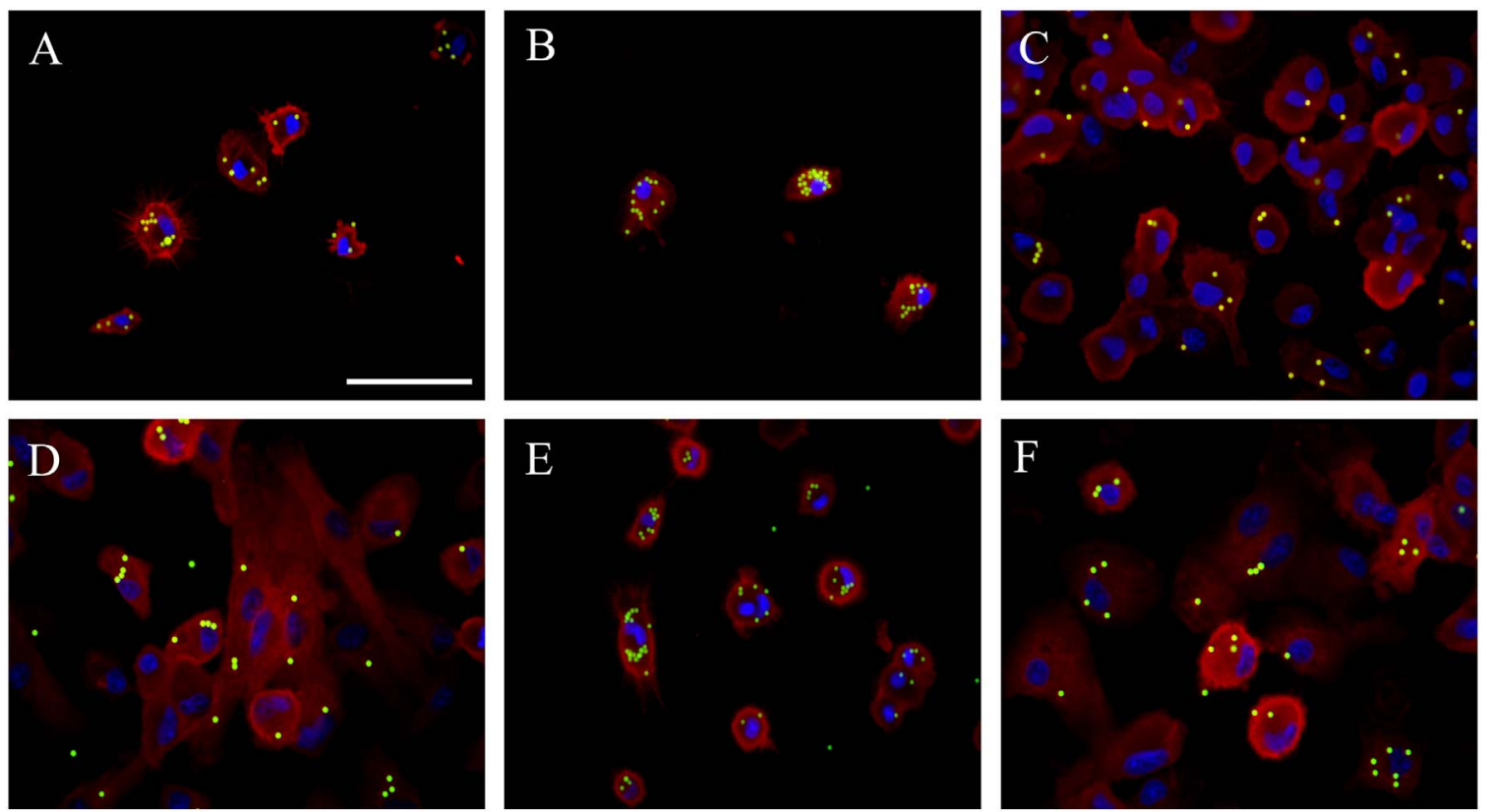

G

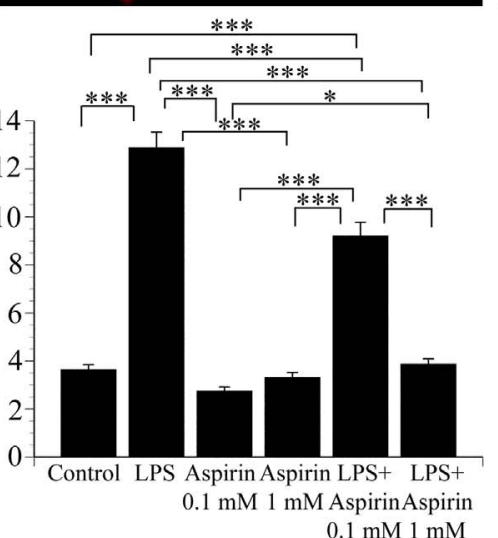

$0.1 \mathrm{mM} 1 \mathrm{mM}$

Fig. 4. Aspirin strongly inhibits phagocytosis.

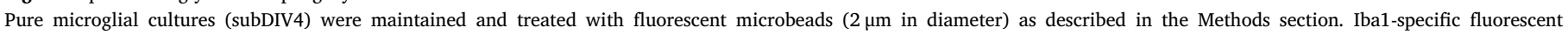

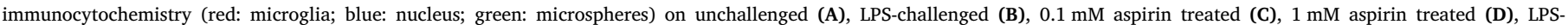

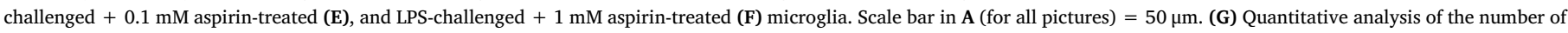

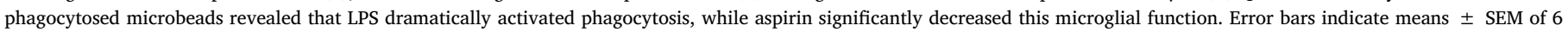
replicate measurements from 3 independent culturing. Data were analyzed with two-way ANOVA. *p $<0.05$, ***p $<0.001$. 

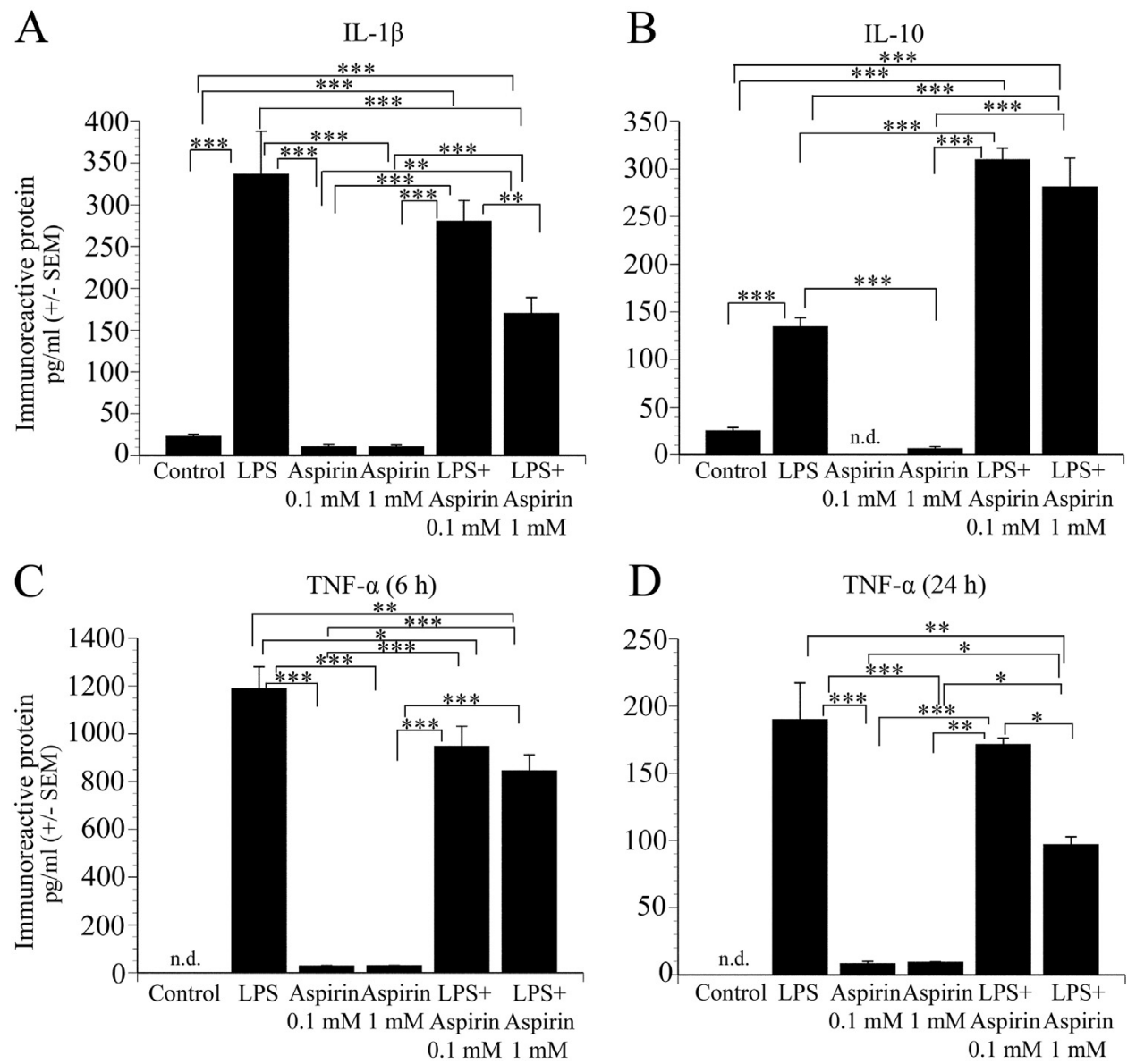

Fig. 5. Aspirin reduces the pro-inflammatory cytokine IL-1 $\beta$ and TNF- $\alpha$ levels and increases the anti-inflammatory IL-10 production

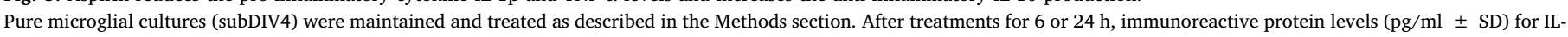

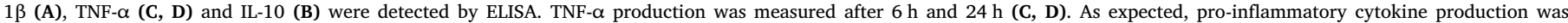

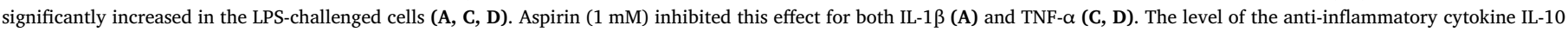

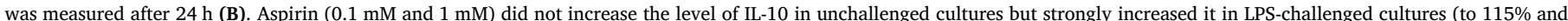

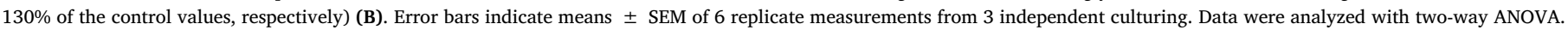
n.d. $=$ not detected. ${ }^{*} \mathrm{p}<0.05 ;{ }^{* *} \mathrm{p}<0.01,{ }^{* * *} \mathrm{p}<0.001$.

microglial genes involved in pro- and anti-inflammatory processes. In unchallenged cells the genes downregulated by aspirin $(0.1 \mathrm{mM}$ or $1 \mathrm{mM}$ ) included the interleukin 1 receptor antagonist (Il1 $\mathrm{rn}=-1.37$ fold; -1.44 -fold), the anti-inflammatory DNA damage inducible transcript 3 (Ddit $=-1.43$-fold, and -1.79 -fold), the pro-inflammatory IL6 (Il6 $=-1.23$-fold; -1.55 -fold) and the pro-inflammatory chemokine (C-C motif) receptor 1 (Ccr1 $=-1.42$-fold, -1.44 -fold). When aspirin was co-administered to LPS-challenged cultures (Table 1), a more complex picture emerged. Some of the LPS-upregulated genes were inhibited by aspirin, as seen in the case of Ccr1 (Fig. 7A), IL1rn (Fig. $7 B$ ) or Nos2 (Fig. 7D). Kng1 (Fig. 7C), a pro-inflammatory gene was downregulated by both aspirin treatments following LPS challenge. Other genes were further upregulated by aspirin when applied to LPSchallenged microglia such as Ccl5 or Csf2, or the pro-inflammatory Ccl4 (Table 1).

\section{Discussion}

Microglial activation results in profound morphological, functional and gene expression changes that activate both pro- and anti-inflammatory mechanisms (Kroner et al., 2014) that in turn not only protect the nervous tissue but can elicit chronic inflammation that could lead to the development of neuropathological conditions (Jones and Thomsen, 2013; Long-Smith et al., 2009). Aspirin, one of the most commonly used drugs, is noted for its strong anti-inflammatory actions. It acetylates the active site of the enzyme COX, and irreversibly blocks the conversion of arachidonic acid to prostanoid (Vane and Botting, 2003). Apart from its classical beneficial role in cardiovascular diseases, however, aspirin may be beneficial in neuroinflammation-related disorders given that appropriate target cells, the microglia, are present in the nervous tissue.

In the present study we investigated the complex pleiotropic, beneficial effects of aspirin on the modulation of inflammation by quantitatively analyzing numerous morphological, functional (phagocytosis, cytokine release) and gene expression parameters in pure, secondary microglial cultures. As our cultures were $>99 \%$ pure, they provided a unique opportunity to study these functional and expression parameters without the significant influence of any contaminating cell types. This is a crucial factor when, for example, the levels of secreted pro- and anti-inflammatory peptides or gene expression levels are measured, as other cell types in the CNS are also capable of expressing such genes (Gruol et al., 2014).

Aspirin reversed the morphological effects of LPS-induced microglia activation through the increase of the area, perimeter and TI values; the combined treatment with LPS also inhibited this activation through the development of microspikes and inducing the cells to become more ramified. Aspirin also affected the protein synthesis of $\mathrm{Iba1}, \mathrm{a} \mathrm{Ca}^{2+}$. binding protein that is implicated in actin cytoskeleton remodeling (Ohsawa et al., 2004; Szabo et al., 2016).

LPS is a potent activator of microglial phagocytosis (Kata et al., 2016; Lund et al., 2006; Szabo and Gulya, 2013; Szabo et al., 2016), a 


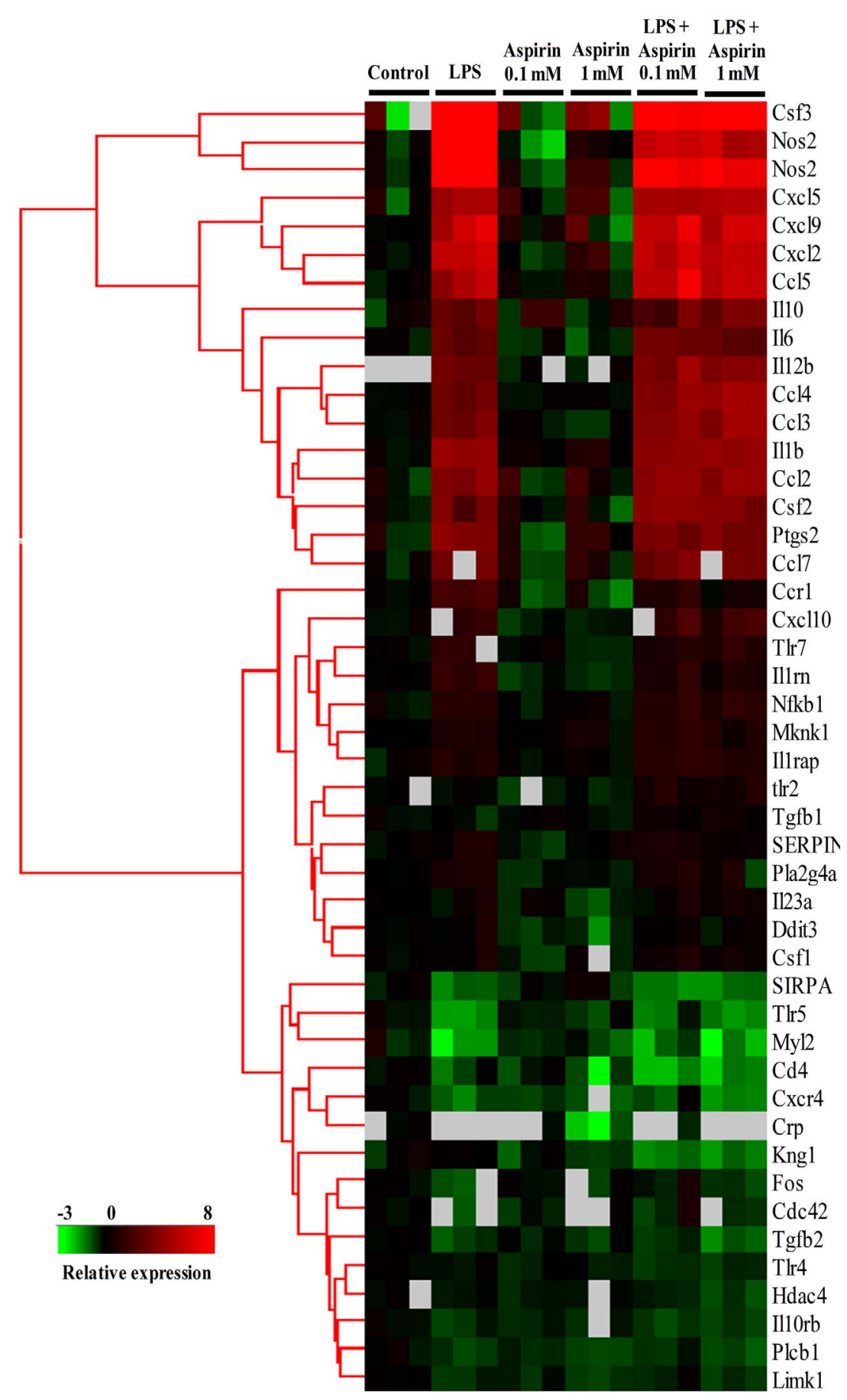

Fig. 6. Hierarchical cluster analysis of inflammation related genes.

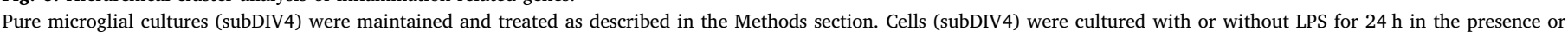

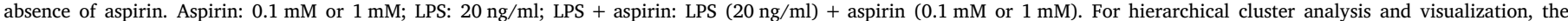

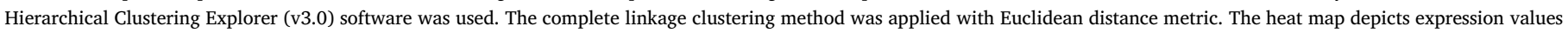
relative to control samples on a $\log _{2}$ scale (overexpression: red, repression: green and no change: black). Missing values are indicated in grey.

crucial factor both in normal and pathologic functions of the CNS (Kettenmann et al., 2011). Alteration of this function could be harmful (Hickman and El Khoury, 2014; Lue et al., 2015). Pro-inflammatory phenotypes are associated with increased phagocytic activity, and blocking of phagocytosis may prevent some forms of inflammatory neurodegeneration; this may be beneficial under different neuropathological conditions (He et al., 2014; Neher et al., 2011). Aspirin inhibited phagocytosis in the LPS-challenged microglia only, while it did not inhibit the basal phagocytotic activity in unchallenged cells, a physiological microglial function crucial for the healthy CNS.
LPS is the main ligad for Toll-like receptor 4 (TLR4). TLR4-induced signalling activates the NF- $\mathrm{KB}$ and MAPK pathways leading to the production of pro-inflammatory cytokines (Fuentes et al., 2016; Korneev et al., 2017). Aspirin inhibits the production of pro-inflammatory cytokines through the suppression of LPS-induced NF- $\mathrm{KB}$ and MAPK pathways in microglial cells (Cianciulli et al., 2016; Sun et al., 2017; Yang et al., 2014). NF-kB activity is suppressed in the cytoplasm with an inhibitory I $\mathrm{kB}$ protein. The phosphorylation and degradation of

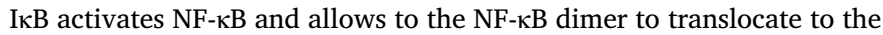
nucleus and activate target genes such as $I L 1 \beta$ and TNF- $\alpha$ (Sun et al., 
Table 1

Differentially expressed transcripts in aspirin-treated pure microglial cells with or without LPS challenge.

\begin{tabular}{|c|c|c|c|c|c|c|}
\hline Gene & $\begin{array}{l}\text { Name } \\
\text { NCBI Reference Sequence ID } \\
\text { RGD ID }\end{array}$ & LPS & Aspirin $0.1 \mathrm{mM}$ & Aspirin $1 \mathrm{mM}$ & LPS + Aspirin $0.1 \mathrm{mM}$ & LPS + Aspirin $1 \mathrm{mM}$ \\
\hline Ccl2 & $\begin{array}{l}\text { Chemokine ligand } 2 \\
\text { NM_031530.1 } \\
\text { RGD ID } 3645\end{array}$ & +16.95 & +1.14 & +1.70 & +20.92 & +21.35 \\
\hline $\mathrm{Ccl} 3$ & $\begin{array}{l}\text { Chemokine ligand } 3 \\
\text { NM_013025.2 } \\
\text { RGD ID } 3647\end{array}$ & +11.33 & -1.01 & -1.31 & +18.41 & +24.79 \\
\hline Ccl4 & $\begin{array}{l}\text { Chemokine ligand } 4 \\
\text { NM_053858.1 } \\
\text { RGD ID } 620441\end{array}$ & +9.80 & -1.05 & +1.06 & +17.68 & +29.80 \\
\hline Ccl5 & $\begin{array}{l}\text { Chemokine ligand } 5 \\
\text { NM_031116.3 } \\
\text { RGD ID } 69069\end{array}$ & +38.26 & +1.02 & +1.35 & +84.12 & +62.69 \\
\hline Ccl7 & $\begin{array}{l}\text { Chemokine ligand } 7 \\
\text { NM_001007612.1 } \\
\text { RGD ID } 1359152\end{array}$ & +11.48 & -1.14 & +1.50 & +10.82 & +11.82 \\
\hline Ccr1 & $\begin{array}{l}\text { Chemokine receptor } 1 \\
\text { NM_020542.2 } \\
\text { RGD ID } 708446\end{array}$ & +4.51 & -1.42 & -1.44 & +2.16 & +1.29 \\
\hline Cxcl1 & $\begin{array}{l}\text { Chemokine ligand } 1 \text { (melanoma growth-stimulating activity, alpha) } \\
\text { NM_030845.1 } \\
\text { RGD ID } 619869\end{array}$ & +84.30 & -1.51 & +4.11 & +43.46 & +246.78 \\
\hline Cxcl2 & $\begin{array}{l}\text { Chemokine ligand } 2 \\
\text { NM_053647.1 } \\
\text { RGD ID } 70069\end{array}$ & +69.02 & -1.37 & +1.73 & +63.70 & +60.07 \\
\hline Cxcl5 & $\begin{array}{l}\text { Chemokine ligand } 5 \text { (Cxcl6) } \\
\text { NM_022214.1 } \\
\text { RGD ID } 708540\end{array}$ & +33.19 & +1.41 & +2.11 & +34.89 & +46.37 \\
\hline Cxcl9 & $\begin{array}{l}\text { Chemokine ligand } 9 \\
\text { NM_145672.4 } \\
\text { RGD ID } 628798\end{array}$ & +73.44 & +1.40 & +1.22 & +86.22 & +68.51 \\
\hline Cxcl10 & $\begin{array}{l}\text { Chemokine ligand } 10 \\
\text { NM_139089.1 } \\
\text { RGD ID } 620209\end{array}$ & +2.83 & -1.30 & -1.24 & +3.93 & +3.21 \\
\hline Csf1 & $\begin{array}{l}\text { Colony stimulating factor-1 } \\
\text { AF515736.1 } \\
\text { RGD ID621063 }\end{array}$ & +1.31 & -1.49 & -1.03 & +1.48 & +1.30 \\
\hline Csf2 & $\begin{array}{l}\text { Colony stimulating factor-2 } \\
\text { XM_001074265.1(old) } \\
\text { NM_053852.1 } \\
\text { RGD ID621065 }\end{array}$ & +10.01 & +1.20 & -1.00 & +20.66 & +14.84 \\
\hline Csf3 & $\begin{array}{l}\text { Colony stimulating factor } 3 \\
\text { NM_017104.1 (old), NM_017104.2 } \\
\text { RGD ID } 2426\end{array}$ & +305.58 & +1.23 & +4.96 & +282.90 & +278.46 \\
\hline Ddit3 & $\begin{array}{l}\text { DNA-damage inducible transcript } 3 \\
\text { NM_001109986.1 } \\
\text { RGD ID } 62391\end{array}$ & +1.25 & -1.43 & -1.79 & +1.14 & +1.04 \\
\hline Il1 $\beta$ & $\begin{array}{l}\text { Interleukin } 1 \text { beta } \\
\text { NM_031512.2 } \\
\text { RGD ID } 2891\end{array}$ & +24.70 & +1.18 & +1.62 & +19.88 & +22.98 \\
\hline Il1rap & $\begin{array}{l}\text { Interleukin } 1 \text { receptor accessory protein } \\
\text { NM_012968.1 } \\
\text { RGD ID2893 }\end{array}$ & +1.97 & -1.02 & +1.06 & +2.30 & +2.08 \\
\hline Il1rn & $\begin{array}{l}\text { Interleukin } 1 \text { receptor antagonist } \\
\text { NM_022194.2 } \\
\text { RGD ID } 621159\end{array}$ & +2.83 & -1.37 & -1.44 & +2.02 & +1.64 \\
\hline Il6 & $\begin{array}{l}\text { Interleukin } 6 \\
\text { M26744.1 } \\
\text { RGD ID } 2901\end{array}$ & +7.57 & -1.23 & -1.55 & +10.82 & +7.22 \\
\hline Il10 & $\begin{array}{l}\text { Interleukin } 10 \\
\text { NM_012854.2 } \\
\text { RGD ID } 2886\end{array}$ & +8.47 & +2.01 & +1.04 & +6.28 & +11.87 \\
\hline Il18 & $\begin{array}{l}\text { IFN-gamma-inducing factor IL-18 } \\
\text { AY077842.1 } \\
\text { RGD ID } 2889\end{array}$ & +2.24 & +1.63 & -1.29 & +1.90 & +2.03 \\
\hline Kng1 & $\begin{array}{l}\text { Kininogen } 1 \\
\text { NM_012696.2 } \\
\text { RGD ID } 2980\end{array}$ & +1.04 & -1.36 & -1.55 & -2.75 & -2.82 \\
\hline Nos2 & $\begin{array}{l}\text { Nitric oxide synthase } \\
\text { U26686.1 } \\
\text { RGD ID } 3185\end{array}$ & +369.22 & -1.28 & +1.78 & +73.06 & +51.21 \\
\hline Pla2g4a & $\begin{array}{l}\text { Phospholipase A2, group IVA (cytosolic, calcium-dependent) } \\
\text { NM } 133551.2\end{array}$ & +1.73 & -1.33 & -1.16 & +1.66 & +1.07 \\
\hline
\end{tabular}


Table 1 (continued)

\begin{tabular}{|c|c|c|c|c|c|c|}
\hline Gene & $\begin{array}{l}\text { Name } \\
\text { NCBI Reference Sequence ID } \\
\text { RGD ID }\end{array}$ & LPS & Aspirin $0.1 \mathrm{mM}$ & Aspirin $1 \mathrm{mM}$ & LPS + Aspirin $0.1 \mathrm{mM}$ & LPS + Aspirin $1 \mathrm{mM}$ \\
\hline & RGD ID 67366 & & & & & \\
\hline Ptgs2 & $\begin{array}{l}\text { Prostaglandin endoperoxide synthase } 2 \\
\text { NM_017232.3 } \\
\text { RGD ID } 620349\end{array}$ & +16.83 & -1.33 & +2.14 & +11.76 & +12.55 \\
\hline Sirpa & $\begin{array}{l}\text { The signal-regulatory protein a } \\
\text { NM_013016.2 } \\
\text { RGD ID } 3449\end{array}$ & -2.42 & -1.22 & +1.04 & -2.84 & -2.63 \\
\hline Tgfb1 & $\begin{array}{l}\text { Transforming growth factor, beta } 1 \\
\text { NM_021578.2 } \\
\text { RGD ID } 69051\end{array}$ & -1.21 & +1.05 & -1.10 & +1.25 & +1.34 \\
\hline Tgfb2 & $\begin{array}{l}\text { Transforming growth factor, beta } 2 \\
\text { NM_031131.1 } \\
\text { RGD ID } 70491\end{array}$ & -1.73 & -1.15 & -1.43 & -1.47 & -2.41 \\
\hline Tlr2 & $\begin{array}{l}\text { Toll-like receptor } 2 \\
\text { NM_198769.2 } \\
\text { RGD ID } 735138\end{array}$ & -1.03 & -1.49 & -1.22 & +1.63 & +1.63 \\
\hline Tlr7 & $\begin{array}{l}\text { Toll-like receptor } 7 \\
\text { EF032637.1 } \\
\text { RGD ID } 1563357\end{array}$ & +2.71 & +1.05 & -1.36 & +1.79 & +2.21 \\
\hline
\end{tabular}

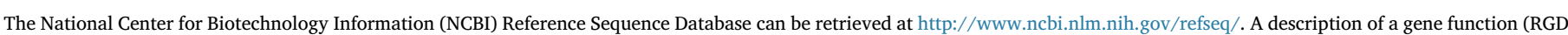

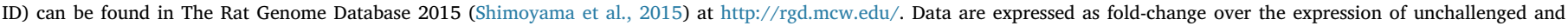

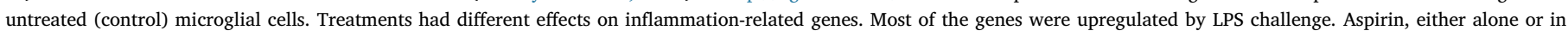

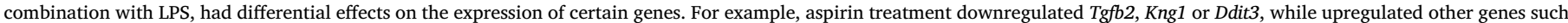

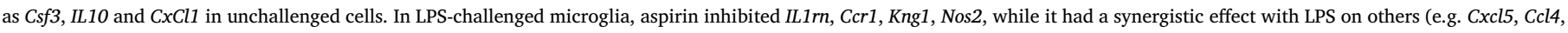
Csf2).

2017; Yang et al., 2014). LPS-stimutated degradation of IkB could be strongly inhibited by aspirin (Yang et al., 2014). Anti-inflammatory property is mediated by inhibition of several members of MAPK family, e.g., p38 MAPK and ERK1/2 (Jung et al., 2009; Li et al., 2017); according to recent data, aspirin enhances the inhibition of p38-MAPK and ERK phosphorylation in a microglial cell line (Yang et al., 2014).

Cytokines are important to the normal and pathologic immunomodulatory functions of the microglia. Previous studies demonstrated a strong relationship between cytokines and neurodegenerative diseases (McGeer and McGeer, 2010; Smith et al., 2012). Microglial cells activated by $\beta$-amyloid deposits produce toxic mediators and proinflammatory cytokines such as IL-1 $\beta$, IL- 6 , TNF- $\alpha$ and iNos that could result in chronic inflammation (Benveniste et al., 2001). High level of IL-1 $\beta$ could be observed in the vicinity of amyloid plaques of $\mathrm{AD}$ patients (McGeer et al., 1993) that could be responsible for plaque accumulation (Akiyama et al., 2000). COX-2 is also increased in AD patients (Akiyama et al., 2000). Recent attempts have been made to ameliorate neuroinflammation through the suppression of microglial activation both in vivo and in vitro (Lim et al., 2015; Wang et al., 2011; Yang et al., 2016). Similarly to the findings for AD, previous studies also suggested that activated microglia could be associated with neuronal loss during PD due to the activation of cytokines, COX-2 and iNos expression (Orr et al., 2002; Phani et al., 2012) or increased levels of TNF- $\alpha$ and nitrogen oxide could cause demyelination in MS (Minagar et al., 2002).

As expected, both pro- (IL-1 $\beta$, TNF- $\alpha$ ) and anti-inflammatory (IL-10) cytokines were increased in LPS-challenged microglia as compared with the unchallenged cells. Aspirin did not significantly affect the basal cytokine levels in unchallenged cells, but strongly reduced the levels of the pro-inflammatory cytokines IL- $1 \beta$ and TNF- $\alpha$ when tested in LPSchallenged microglia. Besides the inhibition of these pro-inflammatory agents, aspirin was also able to elevate the anti-inflammatory IL-10 in LPS-challenged cells. Thus, aspirin is remarkably beneficial as it concomitantly decreased pro-inflammation-related cytokines but increased anti-inflammation-related cytokine peptides in immunochallenged cells.

We also demonstrated that aspirin, LPS and their combination had differential effects on the expression of several inflammation-related genes in pure microglial cells. Some of these genes encode markers that can be related to different microglia subtypes proposed as M1 or M2 phenotypes (Moehle and West, 2015; Orihuela et al., 2016). In this context, for example, the pro-inflammatory IL1 $\beta, I L 6, I L 18, C x c l 9$, TNF$\alpha$, Cxcl10, and the chemokine $C c l 5$, genes encode M1 markers, while the anti-inflammatory $I L 10$ and the pro-inflammatory $T g f b 2$ genes are M2 markers (Franco and Fernández-Suárez, 2015). In an LPS-based animal model for Parkinson's disease, a Rho kinase inhibitor reversed the inflammatory M1 to anti-inflammatory M2 microglia, decreased NF- $\mathrm{KB}$ activation, and inhibited IL-12 and TNF- $\alpha$ generation (He et al., 2016), demonstrating a protective effect against LPS-mediated dopaminergic degeneration. It must be noted, however, that the concept of M1/M2 polarization of microglia cells is not universally accepted and needs reassessment (Martinez and Gordon, 2014; Ransohoff, 2016).

Our study demonstrated that several genes were upregulated after LPS challenge, confirming its strong pro-inflammatory effects on microglia. Aspirin, both alone and in combination with LPS, displayed different effects on microglial gene expression. It suppressed the proinflammatory effects of LPS on some genes such as Ccr1 and Nos2. It may be of importance that $C c r 1$ was previously associated with both MS and experimental autoimmune encephalomyelitis (Rottman et al., 2000) and Ccr1 protein was localized around the demyelinating plaques (Eltayeb et al., 2007). In our experiment (Fig. 7A) both aspirin doses decreased Ccr1 expression. Multiple studies suggested that Nos2 has a central role in inflammatory reactions and pathogenesis of certain neurodegenerative diseases (Akiyama et al., 2000; Block and Hong, 2005; Galea and Feinstein, 1999). Thus, downregulating Nos2 expression could be crucial for possible future therapies. We showed that aspirin inhibited Nos2 expression significantly in LPS-challenged microglia. Kininogen (Kng1) is well known for its pro-inflammatory properties (Sharma and Yusof, 1998; Stewart et al., 1997) as it increases the release of inflammatory cytokines and affects the formation of inflammatory exudate and pain (Ueno and Oh-ishi, 2003).

Aspirin also increased the expression of genes that were predominantly anti-inflammatory e.g. IL10, Tgfb1 or Ccl5. IL-10 is a well known anti-inflammatory cytokine that limits the production of pro-inflammatory cytokines including IL- $1 \alpha$ and $-\beta$, IL- 6 , IL-12, IL-18, and TNF- $\alpha$ (Couper et al., 2008). Previous studies showed that Tgfb1 had a 
A

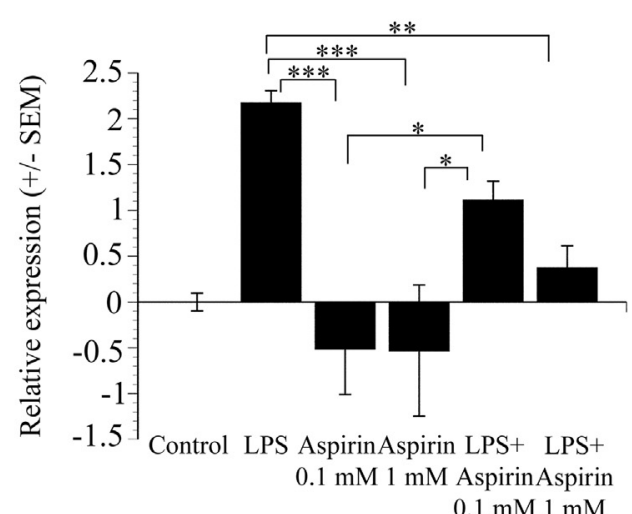

$\mathrm{C}$

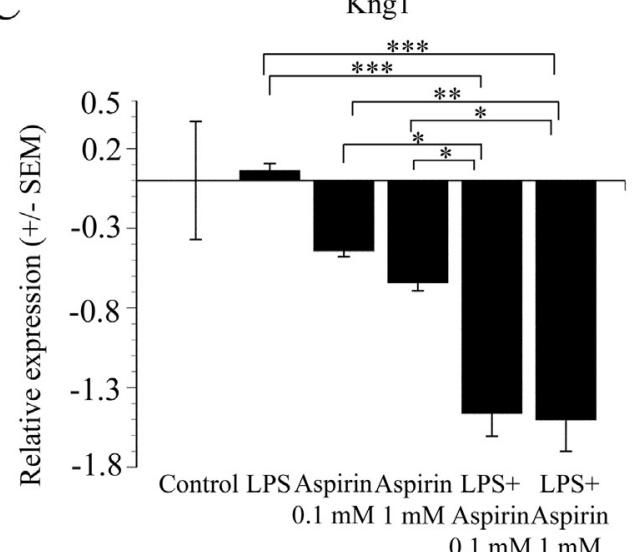

B ILlrn

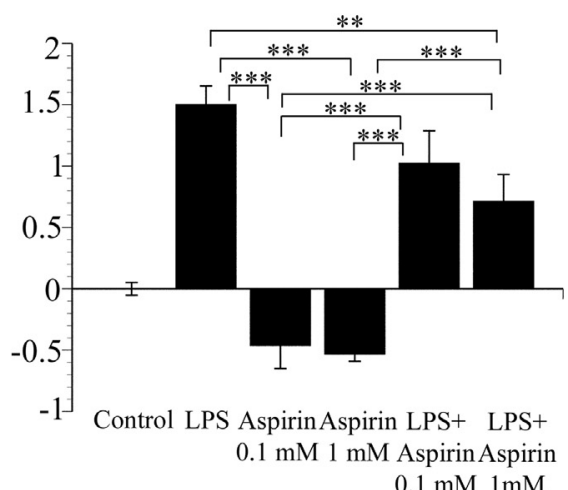

$0.1 \mathrm{mM} 1 \mathrm{mM}$

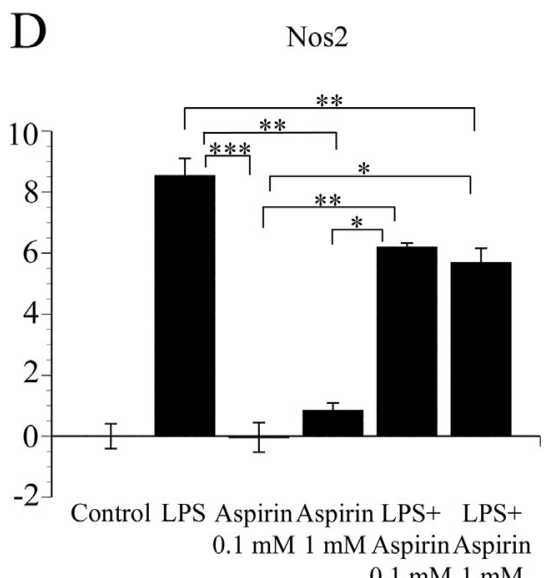

Fig. 7. Relative expression levels of various inflammation-related genes identified by real-time PCR in pure microglia cells.

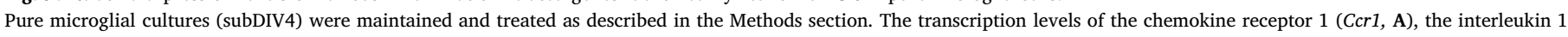

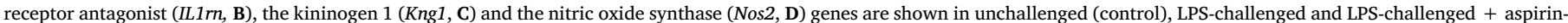

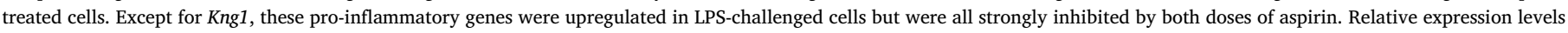
(on a $\log _{2}$ scale) \pm SEM from at least 3 separate experiments are shown for each condition. Data were analyzed with two-way ANOVA. *p $<0.05, * * \mathrm{p}<0.01, * * * \mathrm{p}<0.001$.

protective effect against excitotoxicity and the loss of this protein resulted in neurodegeneration (Brionne et al., 2003). Ccl5 was also upregulated in our studies. Although Ccl5 was demonstrated to induce pro-inflammatory mechanisms (Skuljec et al., 2011), it was also shown to ameliorate $\mathrm{AD}$-like pathology by recruiting microglia to $\beta$-amyloid deposits (Lee et al., 2012) and to protect against neuronal injury (Campbell et al., 2013; Lim and Mocchetti, 2015). Upregulation of such anti-inflammatory genes in neurodegenerative disorders could be beneficial.

As activated microglia often damage neuronal tissues (Hong et al., 2016; Lui et al., 2016) or cause chronic inflammation by excessive cytokine production combined with high level of phagocytosis, effective inhibition of pro-inflammatory actions by aspirin could be an important prophylactic therapy in preventing neuroinflammation and thus neurodegeneration. Our data indicate that aspirin beneficially regulates microglia, cells that could be targets in treating or preventing neurodegenerative disorders. With respect to the large population who receives aspirin for pain medication or prevention of a number of pathologic conditions, to study the interactions of this drug with the nervous system is even more important. Early observations revealed that NSAIDs could reduce the risk of AD (McGeer et al., 1996; Stewart et al., 1997), a notion that has not been proven in randomised controlled trials assessing the efficacies of aspirin, steroidal and nonsteroidal anti-inflammatory drugs in AD (Jaturapatporn et al., 2012). However, we recently demonstrated that rosuvastatin, a new genera- tion 3-hydroxy-3-methylglutaryl coenzyme A reductase inhibitor regulated microglial pro- and anti-inflammatory functions very favorably (Kata et al., 2016). As the effects of aspirin on selected morphological, functional and gene expression characteristics of microglia are very similar to that of rosuvastatin, and these drugs are frequently prescribed together for a number of cardiovascular illnesses, their extended use may have contributed to the lower than expected incidence of $\mathrm{AD}$ (Schrijvers et al., 2012). Thus, the individual and combined effects of aspirin and rosuvastatin on microglial functions should be further analyzed for a prophylactic therapeutic approach in neurodegenerative disorders.

\section{Conclusion}

Aspirin elicits strong responses to microglial functions in LPSchallenged pure microglial cells. The most important pleiotropic beneficial effects of aspirin are 1) the robust inhibition of phagocytosis in activated microglia, 2) the inhibition of synthesis of pro-inflammatory cytokines combined with a very strong stimulation of antiinflammatory cytokine production, and 3) the beneficial differential expression of a number of inflammation-related genes. Such beneficial regulation of microglial functions could point to the possible benefits of aspirin therapy in certain neuroinflammatory and neurodegenerative diseases. 


\section{Author contributions}

This study is based on an original idea of KG. Designed the experiments: LH, LGP and KG. Performed the experiments: DK, IF, LZF and LH. Contributed unpublished reagents/analytic tools: LGP. Analyzed the data: DK, IF and LH. Wrote the paper: DK and KG. All authors have read and approved the final manuscript.

\section{Conflict of interests}

LGP holds an equity position in Avidin Ltd. that produces a highthroughput QPCR product (Rat immune panel) and has a service using the same kit (http://avidinbiotech.com/custom-pathways/).

\section{Acknowledgements}

This work was supported by grants to the University of Szeged from the Ministry of National Resources (GINOP-2.3.2-15-2016-00034 and GINOP-2.3.2-15-2016-00039) through the European Union Cohesion Fund and from the National Development Agency of Hungary (KMR_12_1_2012_0072). The funders had no role in the study design, the data collection and analysis, the decision to publish, or the preparation of the manuscript. At the time of the experiments, D.K. was a Ph.D. student at the University of Szeged.

\section{References}

Ahmed, Z., Shaw, G., Sharma, V.P., Yang, C., McGowan, E., Dickson, D.W., 2007. Actinbinding proteins coronin-1a and IBA-1 are effective microglial markers for immunohistochemistry. J. Histochem. Cytochem. 55, 687-700.

Akiyama, H., Barger, S., Barnum, S., Bradt, B., Bauer, J., Cole, G.M., Cooper, N.R, Eikelenboom, P., Emmerling, M., Fiebich, B.L., et al., 2000. Inflammation and Alzheimer's disease. Neurobiol. Aging 21, 383-421.

Amann, R., Peskar, B.A., 2002. Anti-inflammatory effects of aspirin and sodium salicylate. Eur. J. Pharmacol. 447, 1-9.

Benveniste, E.N., Nguyen, V.T., O'Keefe, G.M., 2001. Immunological aspects of microglia: relevance to Alzheimer's disease. Neurochem. Int. 39, 381-391.

Berk, M., Dean, O., Drexhage, H., McNeil, J.J., Moylan, S., O’Neil, A., Davey, C.G., Sanna, L., Maes, M., 2013. Aspirin: a review of its neurobiological properties and therapeutic potential for mental illness. BMC Med. 11, 74.

Block, M.L., Hong, J.S., 2005. Microglia and inflammation-mediated neurodegeneration: multiple triggers with a common mechanism. Prog. Neurobiol. 76, 77-98.

Brionne, T.C., Tesseur, I., Masliah, E., Wyss-Coray, T., 2003. Loss of TGF-beta 1 leads to increased neuronal cell death and microgliosis in mouse brain. Neuron 40, $1133-1145$.

Campbell, L.A., Avdoshina, V., Rozzi, S., Mocchetti, I., 2013. CCL5 and cytokine expression in the rat brain: differential modulation by chronic morphine and morphine withdrawal. Brain Behav. Immun. 34, 130-140.

Cianciulli, A., Calvello, R., Porro, C., Trotta, T., Salvatore, R., Panaro, M.A., 2016. PI3k/ Akt signalling pathway plays a crucial role in the anti-inflammatory effects of curcumin in LPS-activated microglia. Int. Immunopharmacol. 36, 282-290.

Couper, K.N., Blount, D.G., Riley, E.M., 2008. IL-10: the master regulator of immunity to infection. J. Immunol. 180, 5771-5777.

Cuzick, J., Thorat, M.A., Andriole, G., Brawley, O.W., Brown, P.H., Culig, Z., Eeles, R.A., Ford, L.G., Hamdy, F.C., Holmberg, L., et al., 2014. Prevention and early detection of prostate cancer. Lancet Oncol. 15, e484-e492.

Eltayeb, S., Berg, A.L., Lassmann, H., Wallström, E., Nilsson, M., Olsson, T., EricssonDahlstrand, A., Sunnemark, D., 2007. Temporal expression and cellular origin of CC chemokine receptors CCR1, CCR2 and CCR5 in the central nervous system: insight into mechanism of MOG-induced EAE. J. Neuroinflammation 4, 14.

Fabian, G., Farago, N., Feher, L.Z., Nagy, L.I., Kulin, S., Kitajka, K., Bito, T., Tubak, V., Katona, R.L., Tiszlavicz, L., Puskas, L.G., 2011. High-density real-time PCR-based in vivo toxicogenomic screen to predict organ-specific toxicity. Int. J. Mol. Sci. 12, 6116-6134.

Franco, R., Fernández-Suárez, D., 2015. Alternatively activated microglia and macrophages in the central nervous system. Prog. Neurobiol. 131, 65-86.

Fuentes, E., Rojas, A., Palomo, I., 2016. NF-kB signaling pathway as target for antiplatelet activity. Blood Rev. 30, 309-315.

Fujita, H., Tanaka, J., Toku, R., Tateishi, N., Suzuki, Y., Matsuda, S., Sakanaka, M., Maeda, N., 1996. Effects of GM-CSF and ordinary supplements on the ramification of microglia in culture: a morphometrical study. Glia 18, 269-281.

Galea, E., Feinstein, D.L., 1999. Regulation of the expression of the inflammatory nitric oxide synthase (NOS2) by cyclic AMP. FASEB J. 13, 2125-2137.

Ge, Y.W., Lahiri, D.K., 2002. Regulation of promoter activity of the APP gene by cytokines and growth factors: implications in Alzheimer's disease. Ann. N. Y. Acad. Sci. 973, 463-467.

Gehrmann, J., Matsumo, Y., Kreutzberg, G., 1995. Microglia: intrinsic immunoeffector cell of the brain. Brain Res, Rev, 20, 269-287.

Ghosh, S., Wu, M.D., Shaftel, S.S., Kyrkanides, S., LaFerla, F.M., Olschowka, J.A., O'Banion, M.K., 2013. Sustained interleukin-1ß overexpression exacerbates tau pathology despite reduced amyloid burden in an Alzheimer's mouse model. J. Neurosci. 33, 5053-5064.

Gonzalez-Scarano, F., Baltuch, G., 1999. Microglia as mediators of inflammatory and degenerative diseases. Annu. Rev. Neurosci. 22, 219-240.

Graeber, M.B., 2010. Changing face of microglia. Science 330, 783-788.

Gresa-Arribas, N., Vieitez, C., Dentesano, G., Serratosa, J., Saura, J., Sola, C., 2012. Modelling neuroinflammation in vitro: a tool to test the potential neuroprotective effect of anti-inflammatory agents. PLoS One 7, e45227.

Gruol, D.L., Vo, K., Bray, J.G., 2014. Increased astrocyte expression of IL-6 or CCL2 in transgenic mice alters levels of hippocampal and cerebellar proteins. Front. Cell. Neurosci. 8, 234.

Hanisch, U.K., 2002. Microglia as a source and target of cytokines. Glia 40, 140-155.

He, G.L., Liu, Y., Li, M., Chen, C.H., Gao, P., Yu, Z.P., Yang, X.S., 2014. The amelioration of phagocytic ability in microglial cells by curcumin through the inhibition of EMFinduced pro-inflammatory responses. J. Neuroinflammation 11, 49.

He, Q., Li, Y.H., Guo, S.S., Wang, Y., Lin, W., Zhang, Q., Wang, J., Ma, C.G., Xiao, B.G., 2016. Inhibition of Rho-kinase by Fasudil protects dopamine neurons and attenuates inflammatory response in an intranasal lipopolysaccharide-mediated Parkinson's model. Eur. J. Neurosci. 43, 41-52.

Hickman, S.E., El Khoury, J., 2014. TREM2 and the neuroimmunology of Alzheimer's disease. Biochem. Pharmacol. 88, 495-498.

Higgs, G.A., Salmon, J.A., Henderson, B., Vane, J.R., 1987. Pharmacokinetics of aspirin and salicylate in relation to inhibition of arachidonate cyclooxygenase and antiinflammatory activity. Proc. Natl. Acad. Sci. U. S. A. 84, 1417-1420.

Hong, S., Beja-Glasser, V.F., Nfonoyim, B.M., Frouin, A., Li, S., Ramakrishnan, S., Merry, K.M., Shi, Q., Rosenthal, A., Barres, B.A., Lemere, C.A., Selkoe, D.J., Stevens, B., 2016. Complement and microglia mediate early synapse loss in Alzheimer mouse models. Science 352, 712-716.

Hussain, M., Javeed, A., Ashraf, M., Zhao, Y., Mukhtar, M.M., Rehman, M.U., 2012 Aspirin and immune system. Int. Immunopharmacol. 12, 10-20.

Jaturapatporn, D., Isaac, M.G., McCleery, J., Tabet, N., 2012. Aspirin, steroidal and nonsteroidal anti-inflammatory drugs for the treatment of Alzheimer's disease. Cochrane Database Syst. Rev. 2, CD006378.

Jones, K.A., Thomsen, C., 2013. The role of the innate immune system in psychiatric disorders. Mol. Cell. Neurosci. 53, 52-62.

Jung, H.W., Yoon, C.H., Park, K.M., Han, H.S., Park, Y.K., 2009. Hexane fraction of Zingiberis Rhizoma Crudus extract inhibits the production of nitric oxide and proinflammatory cytokines in LPS-stimulated BV2 microglial cells via the NF-kappaB pathway. Food Chem. Toxicol. 47, 1190-1197.

Kata, D., Gulya, K., 2014. Aspirin regulates the inflammatory responses of activated microglia. Poster No. C112. In: FENS Forum of Neuroscience. July 5-9, 2014, Milan, Italy. p. 219.

Kata, D., Földesi, I., Feher, L.Z., Hackler Jr., L., Puskas, L.G., Gulya, K., 2016. Rosuvastatin enhances anti-inflammatory and inhibits pro-inflammatory functions in cultured microglial cells. Neuroscience 314, 47-63.

Kettenmann, H., Hanisch, U.K., Noda, M., Verkhratsky, A., 2011. Physiology of microglia Physiol. Rev. 91, 461-553.

Korneev, K.V., Atretkhany, K.N., Drutskaya, M.S., Grivennikov, S.I., Kuprash, D.V., Nedospasov, S.A., 2017. TLR-signaling and proinflammatory cytokines as drivers of tumorigenesis. Cytokine 89, 127-135.

Kreutzberg, G.W., 1996. Microglia: a sensor for pathological events in the CNS. Trends Neurosci. 19, 312-318.

Kroner, A., Greenhalgh, A.D., Zarruk, J.G., Passos Dos Santos, R., Gaestel, M., David, S., 2014. TNF and increased intracellular iron alter macrophage polarization to a detrimental M1 phenotype in the injured spinal cord. Neuron 83, 1098-1116.

Lee, J.K., Schuchman, E.H., Jin, H.K., Bae, J.S., 2012. Soluble CCL5 derived from bone marrow-derived mesenchymal stem cells and activated by amyloid $\beta$ ameliorates Alzheimer's disease in mice by recruiting bone marrow-induced microglia immune responses. Stem Cells 30, 1544-1555.

Li, H., Yoon, J.H., Won, H.J., Ji, H.S., Yuk, H.J., Park, K.H., Park, H.Y., Jeong, T.S., 2017 Isotrifoliol inhibits pro-inflammatory mediators by suppression of TLR/NF- $\mathrm{KB}$ and TLR/MAPK signaling in LPS-induced RAW264.7 cells. Int. Immunopharmacol. 45, 110-119.

Lim, S.T., Mocchetti, I., 2015. Pharmacological induction of CCL5 in vivo prevents gp120mediated neuronal injury. Neuropharmacology 92, 98-107.

Lim, H.W., Park, J.I., More, S.V., Park, J.Y., Kim, B.W., Jeon, S.B., Yun, Y.S., Park, E.J., Yoon, S.H., Choi, D.K., 2015. Anti-neuroinflammatory effects of DPTP, a novel synthetic clovamide derivative in in vitro and in vivo model of neuroinflammation. Brain Res. Bull. 112, 25-34.

Long-Smith, C.M., Sullivan, A.M., Nolan, Y.M., 2009. The influence of microglia on the pathogenesis of Parkinson's disease. Prog. Neurobiol. 89, 277-287.

Lowry, O.H., Rosebrough, N.J., Farr, A.L., Randall, R.J., 1951. Protein measurement with the Folin phenol reagent. J. Biol. Chem. 193, 265-275.

Lue, L.F., Schmitz, C., Walker, D.G., 2015. What happens to microglial TREM2 in Alzheimer's disease: immunoregulatory turned into immunopathogenic? Neuroscience 302, 138-150.

Lui, H., Zhang, J., Makinson, S.R., Cahill, M.K., Kelley, K.W., Huang, H.Y., Shang, Y., Oldham, M.C., Martens, L.H., Gao, F., Coppola, G., et al., 2016. Progranulin deficiency promotes circuit-specific synaptic pruning by microglia via complement activation. Cell 165, 921-935.

Lund, S., Christensen, K.V., Hedtiärn, M., Mortensen, A.L., Hagberg, H., Falsig, J., Hasseldam, H., Schrattenholz, A., Pörzgen, P., Leis, M., 2006. The dynamics of the LPS triggered inflammatory response of murine microglia under different culture and 
in vivo conditions. J. Neuroimmunol. 180, 71-87.

Luo, X.G., Chen, S.D., 2012. The changing phenotype of microglia from homeostasis to disease. Transl. Neurodegener. 1, 9.

Martinez, F.O., Gordon, S., 2014. The M1 and M2 paradigm of macrophage activation: time for reassessment. F1000Prime Rep. 6, 13.

McGeer, P.L., McGeer, E.G., 2004. Inflammation and neurodegeneration in Parkinson's disease. Parkinsonism Relat. Disord. 10 (Suppl. 1), S3-S7.

McGeer, E.G., McGeer, P.L., 2010. Neuroinflammation in Alzheimer's disease and mild cognitive impairment: a field in its infancy. J. Alzheimers Dis. 19, 355-361.

McGeer, P.L., Kawamata, T., Walker, D.G., Akiyama, H., Tooyama, I., McGeer, E.G., 1993. Microglia in degenerative neurological disease. Glia 7, 84-92.

McGeer, P.L., Schulzer, M., McGeer, E.G., 1996. Arthritis and anti-inflammatory agents as possible protective factors for Alzheimer's disease: a review of 17 epidemiologic studies. Neurology 47, 425-432.

Medeiros, R., Prediger, R.D., Passos, G.F., Pandolfo, P., Duarte, F.S., Franco, J.L., Dafre, A.L., Di Giunta, G., Figueiredo, C.P., Takahashi, R.N., et al., 2007. Connecting TNFalpha signaling pathways to iNOS expression in a mouse model of Alzheimer's disease: relevance for the behavioral and synaptic deficits induced by amyloid beta protein. J. Neurosci. 27, 5394-5404.

Medeiros, R., Kitazawa, M., Passos, G.F., Baglietto-Vargas, D., Cheng, D., Cribbs, D.H., LaFerla, F.M., 2013. Aspirin-triggered lipoxin A4 stimulates alternative activation of microglia and reduces Alzheimer disease-like pathology in mice. Am. J. Pathol. 182, 1780-1789.

Minagar, A., Shapshak, P., Fujimura, R., Ownby, R., Heyes, M., Eisdorfer, C., 2002. The role of macrophage/microglia and astrocytes in the pathogenesis of three neurologic disorders: HIV-associated dementia, Alzheimer disease, and multiple sclerosis. J. Neurol. Sci. 202, 13-23.

Moehle, M.S., West, A.B., 2015. M1 and M2 immune activation in Parkinson's Disease: foe and ally? Neuroscience 302, 59-73.

Muzio, L., Martino, G., Furlan, R., 2007. Multifaceted aspects of inflammation in multiple sclerosis: the role of microglia. J. Neuroimmunol. 191, 39-44.

Neher, J.J., Neniskyte, U., Zhao, J.W., Bal-Price, A., Tolkovsky, A.M., Brown, G.C., 2011. Inhibition of microglial phagocytosis is sufficient to prevent inflammatory neuronal death. J. Immunol. 186, 4973-4983.

Ohsawa, K., Imai, Y., Sasaki, Y., Kohsaka, S., 2004. Microglia/macrophage-specific protein Iba1 binds to fimbrin and enhances its actin-bundling activity. J. Neurochem. $88,844-856$.

Orihuela, R., McPherson, C.A., Harry, G.J., 2016. Microglial M1/M2 polarization and metabolic states. Br. J. Pharmacol. 173, 649-665.

Phani, S., Loike, J.D., Przedborski, S., 2012. Neurodegeneration and inflammation in Parkinson's disease. Parkinsonism Relat. Disord. 18 (Suppl. 1), S207-S209.

Ransohoff, R.M., 2016. A polarizing question: do M1 and M2 microglia exist? Nat. Neurosci. 19, 987-991.

Rottman, J.B., Slavin, A.J., Silva, R., Weiner, H.L., Gerard, C.G., Hancock, W.W., 2000. Leukocyte recruitment during onset of experimental allergic encephalomyelitis is CCR1 dependent. Eur. J. Immunol. 30, 2372-2377.

Schrijvers, E.M., Verhaaren, B.F., Koudstaal, P.J., Hofman, A., Ikram, M.A., Breteler, M.M., 2012. Is dementia incidence declining?: Trends in dementia incidence since 1990 in the Rotterdam Study. Neurology 78, 1456-1463.
Sharma, J.N., Yusof, A.P., 1998. Pro-inflammatory properties of the kallikrein-kinin system: potential for new drug therapy. Inflammopharmacology 6, 289-296.

Shimoyama, M., De Pons, J., Hayman, G.T., Laulederkind, S.J., Liu, W., Nigam, R., Petri, V., Smith, J.R., Tutaj, M., Wang, S.J., et al., 2015. The Rat Genome Database 2015: genomic, phenotypic and environmental variations and disease. Nucleic Acids Res. 43 (Database Issue), D743-D750.

Shin, W.H., Jeon, M.T., Leem, E., Won, S.Y., Jeong, K.H., Park, S.J., McLean, C., Lee, S.J., Jin, B.K., Jung, U.J., Kim, S.R., 2015. Induction of microglial toll-like receptor 4 by prothrombin kringle-2: a potential pathogenic mechanism in Parkinson's disease. Sci. Rep. 5, 14764.

Skuljec, J., Sun, H., Pul, R., Bénardais, K., Ragancokova, D., Moharregh-Khiabani, D., Kotsiari, A., Trebst, C., Stangel, M., 2011. CCL5 induces a pro-inflammatory profile in microglia in vitro. Cell. Immunol. 270, 164-171.

Smith, J.A., Das, A., Ray, S.K., Banik, N.L., 2012. Role of pro-inflammatory cytokines released from microglia in neurodegenerative diseases. Brain Res. Bull. 87, 10-20.

Stewart, W.F., Kawas, C., Corrada, M., Metter, E.J., 1997. Risk of Alzheimer's disease and duration of NSAID use. Neurology 48, 626-632.

Strauss, K.I., 2008. Antiinflammatory and neuroprotective actions of COX2 inhibitors in the injured brain. Brain Behav. Immun. 22, 285-298.

Streit, W.J., 2002. Microglia as neuroprotective immunocompetent cells of the CNS. Glia 40, 133-139.

Sun, K.Y., Xu, D.H., Xie, C., Plummer, S., Tang, J., Yang, X.F., Ji, X.H., 2017. Lactobacillus paracasei modulates LPS-induced inflammatory cytokine release by monocytemacrophages via the up-regulation of negative regulators of NF-kappaB signaling in a TLR2-dependent manner. Cytokine 92, 1-11.

Szabo, M., Gulya, K., 2013. Development of the microglial phenotype in culture. Neuroscience 241, 280-295.

Szabo, M., Dulka, K., Gulya, K., 2016. Calmodulin inhibition regulates morphological and functional changes related to the actin cytoskeleton in pure microglial cells. Brain Res. Bull. 120, 41-57.

Ueno, A., Oh-ishi, S., 2003. Roles for the kallikrein-kinin system in inflammatory exudation and pain: lessons from studies on kininogen-deficient rats. J. Pharmacol. Sci. 93, 1-20.

Vane, J.R., Botting, R.M., 2003. The mechanism of action of aspirin. Thromb. Res. 110, 255-258.

Wang, Y.P., Wu, Y., Li, L.Y., Zheng, J., Liu, R.G., Zhou, J.P., Yuan, S.Y., Shang, Y., Yao, S.L., 2011. Aspirin-triggered lipoxin A4 attenuates LPS-induced pro-inflammatory responses by inhibiting activation of NF-kB and MAPKs in BV-2 microglial cells. J. Neuroinflammation 8, 95.

Woudstra, C., Lambert, D., Anniballi, F., De Medici, D., Austin, J., Fach, P., 2013. Genetic diversity of the flagellin genes of Clostridium botulinum groups I and II. Appl. Environ. Microbiol. 79, 3926-3932.

Wu, Y., Wu, M., He, G., Zhang, X., Li, W., Gao, Y., Li, Z., Wang, Z., Zhang, C., 2012. Glyceraldehyde-3-phosphate dehydrogenase: a universal internal control for Western blots in prokaryotic and eukaryotic cells. Anal. Biochem. 423, 15-22.

Yang, J.M., Rui, B.B., Chen, C., Chen, H., Xu, T.J., Xu, W.P., Wei, W., 2014. Acetylsalicylic acid enhances the anti-inflammatory effect of fluoxetine through inhibition of NF-kB, p38-MAPK and ERK1/2 activation in lipopolysaccharide-induced BV-2 microglia cells. Neuroscience 275, 296-304. 